\title{
Filling Knowledge Gaps with Five Fuel Cycle Studies
}

Steven J. Piet

Jess Gehin

William Halsey

Temitope Taiwo

November 2010

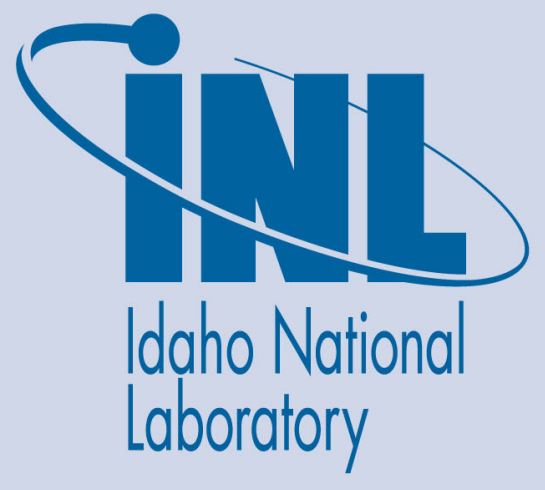

The INL is a U.S. Department of Energy National Laboratory operated by Battelle Energy Alliance 
INL/EXT-10-20720

FCR\&D-SYSA-2011-000011

\title{
Filling Knowledge Gaps with Five Fuel Cycle Studies
}

\author{
Steven J. Piet \\ Jess Gehin ${ }^{3}$ \\ William Halsey ${ }^{2}$ \\ Temitope Taiwo ${ }^{1}$ \\ ${ }^{1}$ Argonne National Laboratory \\ ${ }^{2}$ Lawrence Livermore National Laboratory \\ ${ }^{3}$ Oak Ridge National Laboratory
}

November 2010

\author{
Idaho National Laboratory \\ Fuel Cycle Research \& Development \\ System Analysis Campaign \\ Idaho Falls, Idaho 83415
}

htto://www.inl.qov

Prepared for the

U.S. Department of Energy

Office of Nuclear Energy

Under DOE Idaho Operations Office

Contract DE-AC07-05ID14517 


\section{DISCLAIMER}

This information was prepared as an account of work sponsored by an agency of the U.S. Government. Neither the U.S. Government nor any agency thereof, nor any of their employees, makes any warranty, expressed or implied, or assumes any legal liability or responsibility for the accuracy, completeness, or usefulness, of any information, apparatus, product, or process disclosed, or represents that its use would not infringe privately owned rights. References herein to any specific commercial product, process, or service by trade name, trade mark, manufacturer, or otherwise, does not necessarily constitute or imply its endorsement, recommendation, or favoring by the U.S. Government or any agency thereof. The views and opinions of authors expressed herein do not necessarily state or reflect those of the U.S. Government or any agency thereof. 



\section{SUMMARY}

During FY 2010, five studies were conducted of technology families' applicability to various fuel cycle strategies to fill in knowledge gaps in option space and to better understand trends and patterns. Here, a "technology family" is considered to be defined by a type of reactor and by selection of which actinides provide fuel. This report summarizes the higher-level findings; the detailed analyses and results are documented in five individual reports, as follows:

- Advanced once through with uranium fuel in fast reactors (SFR) [Kim2010],

- Advanced once through (uranium fuel) or single recycle (TRU fuel) in high temperature gas cooled reactors (HTGR) [Piet2010b],

- Sustained recycle with Th/U-233 in light water reactors (LWRs) [Yun2010],

- $\quad$ Sustained recycle with Th/U-233 in molten salt reactors (MSR) [Gehin2010], and

- Several fuel cycle missions with Fusion-Fission Hybrid (FFH) [Halsey2010].

Each study examined how the designated technology family could serve one or more designated fuel cycle missions, filling in gaps in overall option space. Each study contains one or more illustrative cases that show how the technology family could be used to meet a fuel cycle mission, as well as broader information on the technology family such as other potential fuel cycle missions for which insufficient information was available to include with an illustrative case. None of the illustrative cases can be considered as a reference, baseline, or nominal set of parameters for judging performance; the assessments were designed to assess areas of option space and were not meant to be optimized. There is no implication that any of the cases or technology families are necessarily the best way to meet a given fuel cycle mission.

The studies provide five examples of 1-year fuel cycle assessments of technology families. Although each study was budgeted up to $0.5 \mathrm{FTE}$, the true cost of each (if done "from scratch") would be several times higher since each study leveraged other past and current efforts. There is reasonable coverage in the five studies of the performance areas of waste management and uranium utilization. The coverage of economics, safety, and proliferation resistance and physical protection in the five studies was spotty. Some studies did not have existing or past work to draw on in one or more of these areas. Resource constraints limited the amount of new analyses that could be performed. Little or no assessment was done of how soon any of the technologies could be deployed and therefore how quickly they could impact domestic or international fuel cycle performance. There were six common R\&D needs, such as the value of advanced fuels, cladding, coating, and structure that would survive high neutron fluence.

Each of the study reports could be updated in the future as new information becomes available on the illustrative cases studied this year or as new illustrative cases are analyzed. In this sense, they can be considered living documents.

When a technology family is considered for use in a new fuel cycle mission, fuel cycle performance characteristics are dependent on both the design choices and the fuel cycle approach. For example, the use of the sodium-cooled fast reactor to provide recycle in either breeder or burner mode has been studied for decades, but the SFR could be considered for once-through fuel cycle with the physical reactor design and fuel management parameters changed. In addition, the sustained recycle with Th/U-233 in LWR could be achieved with a heterogeneous assembly and derated power density. Therefore, it may or may not be adjustable for other fuel cycle missions although a reactor intended for one fuel cycle mission is built. Simple parameter adjustment in applying a technology family to a new fuel cycle mission should be avoided and, if observed, the results viewed with caution. 
Table S-1 summarizes the illustrative cases studied in the five studies of technology families, together with other parts of option space covered in previous studies and which parts may warrant future study.

Table S-1. Option Space Summary for Five Technology Families (legend below).

\begin{tabular}{|c|c|c|c|c|c|c|c|}
\hline $\begin{array}{l}\text { Recycle or } \\
\text { not? }\end{array}$ & \multicolumn{2}{|c|}{$\begin{array}{l}\text { What is } \\
\text { disposed? }\end{array}$} & $\begin{array}{l}\text { Light Water } \\
\text { Reactor } \\
\text { (LWR) }\end{array}$ & $\begin{array}{c}\text { High } \\
\text { Temperature } \\
\text { Gas Reactor } \\
\text { (HTGR) }\end{array}$ & $\begin{array}{l}\text { Sodium Fast } \\
\text { Reactor } \\
\text { (SFR) }\end{array}$ & $\begin{array}{l}\text { Molten Salt } \\
\text { Reactor } \\
\text { (MSR) }\end{array}$ & $\begin{array}{l}\text { Fusion- } \\
\text { Fission } \\
\text { (FFH) }\end{array}$ \\
\hline \multirow[b]{2}{*}{$\begin{array}{l}\text { Once } \\
\text { through }\end{array}$} & \multicolumn{2}{|c|}{$\begin{array}{l}\text { Unprocessed } \\
\text { used fuel }\end{array}$} & $\begin{array}{l}\text { Burnup } \\
\text { from } 33 \text { to } \\
100 \mathrm{MWth}- \\
\text { day/kg }\end{array}$ & $\begin{array}{l}\text { Pebble bed, } \\
\text { Prismatic }\end{array}$ & Breed and burn & & $\begin{array}{l}\text { Once through } \\
\text { deep-burn - } \\
\text { consume } \\
\text { fissionable } \\
\text { material }\end{array}$ \\
\hline & \multicolumn{2}{|c|}{$\begin{array}{l}\text { Process used } \\
\text { fuel only to } \\
\text { reduce } \\
\text { disposal mass } \\
\text { from non-fuel } \\
\text { hardware }\end{array}$} & $\begin{array}{l}\mathrm{N} / \mathrm{A}- \\
\text { relatively } \\
\text { little to be } \\
\text { gained }\end{array}$ & $\begin{array}{l}\text { Assembly/fuel } \\
\text { mass ratio is } \\
\text { high, reduce by } \\
\text { separating fuel } \\
\text { from bulk } \\
\text { graphite }\end{array}$ & $\begin{array}{l}\text { Assembly/fuel } \\
\text { mass ratio is } \\
\text { high, reduce by } \\
\text { separating fuel } \\
\text { from structure }\end{array}$ & & \\
\hline $\begin{array}{l}\text { Single } \\
\text { recycle }\end{array}$ & \multicolumn{2}{|c|}{$\begin{array}{l}\text { RU/DU, } \\
\text { fission } \\
\text { products, used } \\
\text { fuel }\end{array}$} & $\begin{array}{l}\text { IMF } \\
\text { 1-pass } \\
\text { MOX }\end{array}$ & $\begin{array}{l}\text { IMF (deep- } \\
\text { burn) in pebble } \\
\text { bed or } \\
\text { prismatic }\end{array}$ & $\begin{array}{l}1 \text { pass of } \\
\text { conventional } \\
\text { SFR }\end{array}$ & & $\begin{array}{l}\text { Fissile fuel } \\
\text { factory - } \\
\text { make fuel for } \\
\text { use in other } \\
\text { reactors }\end{array}$ \\
\hline \multirow{4}{*}{$\begin{array}{l}\text { Sustained } \\
\text { recycle }\end{array}$} & \multirow{2}{*}{\multicolumn{2}{|c|}{$\begin{array}{l}\text { RU/DU, } \\
\text { fission } \\
\text { products, and } \\
\text { processing } \\
\text { losses }\end{array}$}} & $\begin{array}{l}\text { U/Pu- } \\
\text { MOX, } \\
\text { Mix of } \\
\text { UOX \& } \\
\text { IMF }\end{array}$ & $\begin{array}{l}\text { MOX, } \\
\text { Mix of UOX \& } \\
\text { IMF (needs } \\
\text { more study) }\end{array}$ & $\begin{array}{l}\text { Conversion ratio } \\
\text { from } 0.0 \text { to } 1.0\end{array}$ & $\begin{array}{l}\mathrm{U} / \mathrm{Pu} \text { needs } \\
\text { study }\end{array}$ & $\begin{array}{l}\text { Dedicated } \\
\text { waste burner } \\
\text { - trans- } \\
\text { mutation of } \\
\text { fissionable } \\
\text { material that } \\
\text { was unused in } \\
\text { fission } \\
\text { reactors }\end{array}$ \\
\hline & & & Th/U-MOX & $\mathrm{Th} / \mathrm{U}$ & $\begin{array}{l}\text { Th/U needs } \\
\text { study }\end{array}$ & $\begin{array}{l}\text { Th/U } \\
\text { denatured, } \\
\text { Th/U with } \\
\text { periodic } \\
\text { salt } \\
\text { disposal }\end{array}$ & $\begin{array}{l}\mathrm{Th} / \mathrm{U} \text { a } \\
\text { logical } \\
\text { extension }\end{array}$ \\
\hline & \multirow{2}{*}{\multicolumn{2}{|c|}{$\begin{array}{l}\text { Fission } \\
\text { products and } \\
\text { processing } \\
\text { losses }\end{array}$}} & \multirow[t]{2}{*}{ N/A } & \multirow[t]{2}{*}{ N/A } & $\begin{array}{l}\mathrm{U} / \mathrm{Pu}- \\
\text { conversion ratio } \\
\text { from } 1.0 \text { to } 1.7\end{array}$ & $\begin{array}{l}\mathrm{U} / \mathrm{Pu} \text { needs } \\
\text { study }\end{array}$ & \\
\hline & & & & & $\begin{array}{l}\mathrm{Th} / \mathrm{U} \text { needs } \\
\text { study }\end{array}$ & $\begin{array}{l}\mathrm{Th} / \mathrm{U} \\
\text { without } \\
\text { periodic } \\
\text { salt } \\
\text { disposal }\end{array}$ & \\
\hline \multicolumn{2}{|c|}{$\begin{array}{l}\text { Color legend in this } \\
\text { table }\end{array}$} & \multicolumn{2}{|c|}{\begin{tabular}{|l|}
$\begin{array}{l}\text { Previous program } \\
\text { studies }\end{array}$ \\
\end{tabular}} & $\begin{array}{l}\text { Illustrative case } \\
\text { these } 5 \text { studies }\end{array}$ & \multicolumn{2}{|c|}{\begin{tabular}{l|l} 
Limited information \\
in these 5 studies
\end{tabular}} & $\begin{array}{l}\text { possibilities } \\
\text { nting study }\end{array}$ \\
\hline
\end{tabular}

Regarding long-term waste radioactivity, the five studies provide two new observations. First, there are two ways to achieve orders of magnitude of radiotoxicity reduction relative to LWR UOX once through: full/sustained recycle of all TRU (with less than 1\% TRU loss to waste) in pure fission reactors and an external supply of neutrons such as from a FFH (if $99 \%$ of the actinides are consumed). Second, fuel 
cycles that make $\mathrm{Pu}-239$ and $\mathrm{U}-233$ without consuming most of it can have higher radiotoxicity in the time period of 1,000 to 100,000 years than U-235 based systems. However, in such systems driven by $\mathrm{Pu}-239$ and $\mathrm{U}-233$, the very long-term radiotoxicity (1,000,000 years) appears lower than U-235 based systems because there is less residual uranium in waste. True sustained recycle with U-233 requires more study.

Regarding ore utilization, the five studies fill in parts of Table S-2, which summarizes actinide ore utilization.

Table S-2. Uranium and Thorium Resource Utilization Summary

\begin{tabular}{|c|c|c|c|}
\hline & \multirow{2}{*}{$\begin{array}{c}\text { Uranium-Plutonium Cycles } \\
\text { (U-235 or Pu-239 driven) }\end{array}$} & \multicolumn{2}{|c|}{$\begin{array}{c}\text { Thorium-Uranium Cycles } \\
\text { (U-233 driven) }\end{array}$} \\
\hline & & Uranium ore & Thorium ore \\
\hline $\begin{array}{l}\text { Thermal } \\
\text { reactors } \\
\text { once through }\end{array}$ & $<1 \%$ & $<1 \%$ & $<2 \%$ \\
\hline \multirow{4}{*}{$\begin{array}{l}\text { Thermal } \\
\text { reactors } \\
\text { sustained } \\
\text { recycle (a) }\end{array}$} & \multirow[t]{4}{*}{$\leq 1 \%$} & $\begin{array}{l}\text { Depends on source of } \\
\text { initial U233. }\end{array}$ & $\begin{array}{l}\text { MSR with initial U233 } \\
\text { loading }-8 \%(b)\end{array}$ \\
\hline & & $\begin{array}{l}\text { MSR with initial U235 } \\
\text { loading }-6 \%\end{array}$ & $\begin{array}{l}\text { MSR with initial U235 } \\
\text { loading }-8 \% \text { (b) }\end{array}$ \\
\hline & & Denatured MSR - 1\% & Denatured MSR - $15 \%(b)$ \\
\hline & & $\begin{array}{l}\text { Depends on source of } \\
\text { initial U233 }\end{array}$ & $\begin{array}{l}\text { LWR-Th/U233 - } 95 \% \text { at } \\
0.1 \% \text { loss } / \text { recycle, } 65 \% \text { at } \\
1 \% \text { loss } / \text { recycle. }\end{array}$ \\
\hline $\begin{array}{l}\text { Fast reactors } \\
\text { once through }\end{array}$ & $\begin{array}{l}\text { As high as } 30 \% \text { if very high } \\
\text { neutron fluence materials can } \\
\text { be developed }\end{array}$ & $\begin{array}{l}\text { Depends on source of } \\
\text { initial U233 }\end{array}$ & $\begin{array}{l}\text { The attainable burnup is } \\
\text { not clear because it is } \\
\text { dependent on U- } 233 \\
\text { fraction but limited by } \\
\text { excess reactivity control. }\end{array}$ \\
\hline $\begin{array}{l}\text { Fast reactors } \\
\text { sustained } \\
\text { recycle (a) }\end{array}$ & $\begin{array}{l}\text { Burners - } 1 \% \\
\text { Breeders - } 80 \text { to } 100 \% \\
\text { depending on which TRU are } \\
\text { recycled and processing losses }\end{array}$ & $\begin{array}{l}\text { Depends on source of } \\
\text { initial U233 }\end{array}$ & $\begin{array}{l}\text { Breeders - if all actinides } \\
\text { recycled, should be } \\
\text { limited only by processing } \\
\text { losses }\end{array}$ \\
\hline $\begin{array}{l}\text { FFH once } \\
\text { through deep- } \\
\text { burn }\end{array}$ & $\begin{array}{l}\sim 99 \% \text { assuming very deep } \\
\text { burn fuels }\end{array}$ & $\begin{array}{l}\text { Initial } U 233 \text { not } \\
\text { required }\end{array}$ & $\begin{array}{l}\sim 99 \% \text { assuming very } \\
\text { deep burn fuels }\end{array}$ \\
\hline \multicolumn{4}{|c|}{$\begin{array}{l}\text { a. For sustained recycle, the utilization is burnup / (burnup + effective loss rate), where burnup is the } \\
\text { percent of heavy metal fissioned each pass through the reactor. The effective loss rate is the } \\
\text { process loss rate of recycled actinides plus the amount of minor actinides discarded (if any). } \\
\text { b. The MSR ore utilization results are constrained because salt fuel/coolant is periodically discarded } \\
\text { in the original MSR concept and thus much thorium is discarded. That is, the effective loss rate is } \\
\text { large. Were online cleanup more effective, the salt would not be discarded and higher utilization } \\
\text { would be possible. In this case, Th utilization would be increased to a value limited by separations } \\
\text { losses similar to sustained recycle in other systems. }\end{array}$} \\
\hline
\end{tabular}


This page intentionally left blank. 


\section{CONTENTS}

SUMMARY iii

ACRONYMS ix

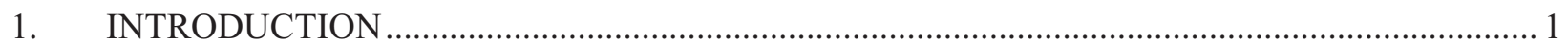

$1.1 \quad$ Purpose

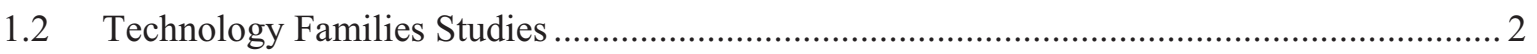

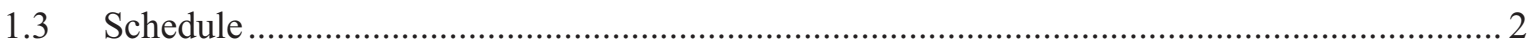

2. THE COMMON REPORT TEMPLATE AND ITS VALUE .................................................. 5

3. ASSESSING HOW AN OPTION CAN SERVE A FUEL CYCLE ............................................. 7

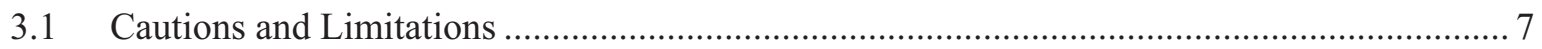

3.2 Adapting a Technology Family to a New Fuel Cycle Mission ............................................ 7

3.3 Adapting a Reactor Built for One Fuel Cycle to Another..................................................... 8

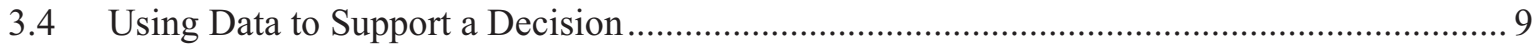

4. OBSERVING PERFORMANCE TRENDS AMONG FAMILIES ............................................. 13

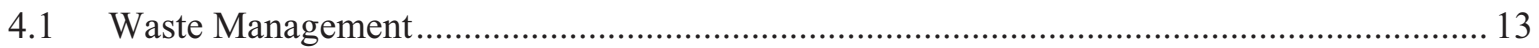

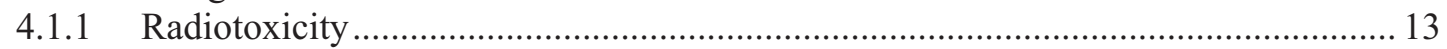

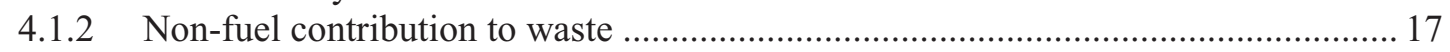

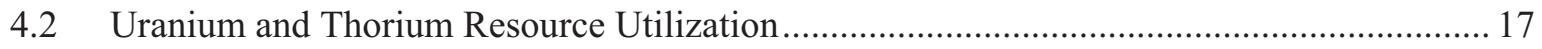

4.3 Proliferation Resistance and Physical Protection................................................................ 20

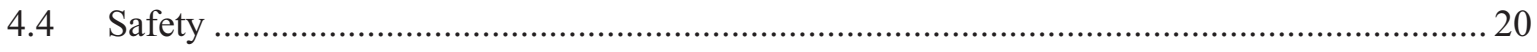

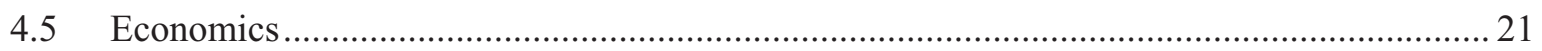

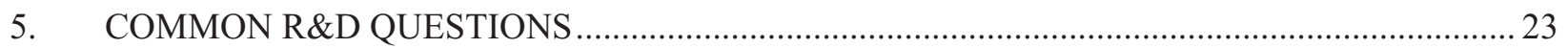

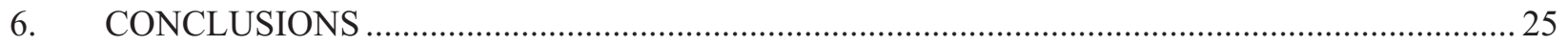

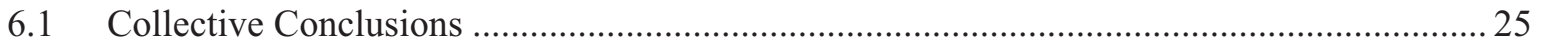

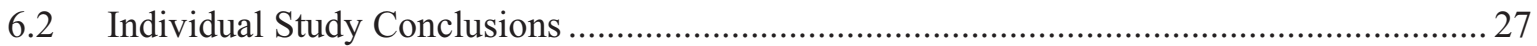

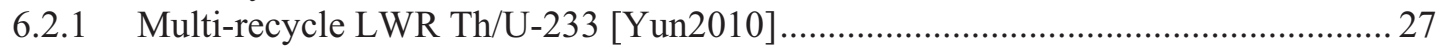

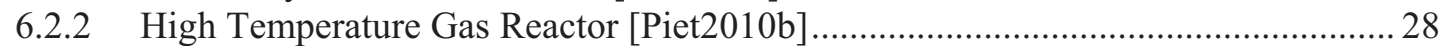

6.2.3 Advanced once through in fast reactors [Kim2010] ............................................... 29

6.2.4 Thorium-fueled Molten Salt Reactor [Gehin2010] .................................................. 30

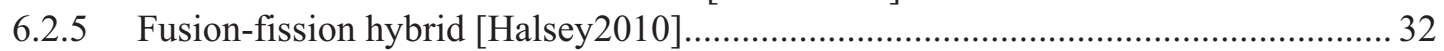

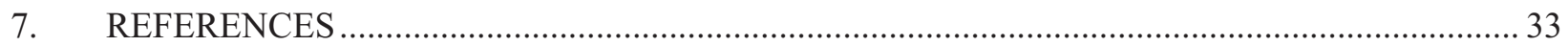

\section{FIGURES}

Figure 3-1. Relationship among data, information, knowledge, and wisdom. ….................................. 10

Figure 4-1. Radiotoxicity for a wide range of uranium-TRU fuel cycles.............................................. 14 
Figure 4-2. Radiotoxicity for breed and burn (once through) fast reactors, much $\mathrm{Pu}-239$ is made without consuming "all" of it.

Figure 4-3. Radiotoxicity for "single charge and dispose" reactors charged with Th/U233; much U-233 is used without consuming "all" of it. 16

\section{TABLES}

Table S-1. Option Space Summary for Five Technology Families (legend below). .................................iv

Table S-2. Uranium and Thorium Resource Utilization Summary .............................................................

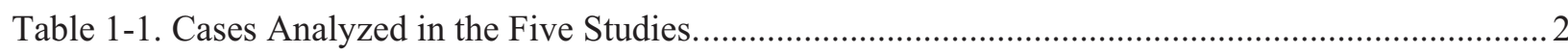

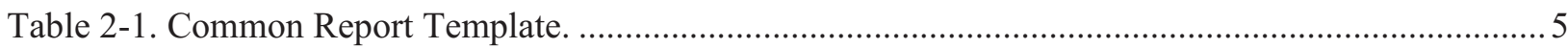

Table 3-1. Adaptability of a Reactor Built for One Fuel Cycle to Serve a Different Fuel Cycle................ 9

Table 4-1. Mass of Fuel Assemblies in Various Options........................................................................ 17

Table 4-2. Uranium and Thorium Resource Utilization Summary ........................................................ 19

Table 4-3. Degree of Consideration of Proliferation Resistance and Physical Protection.........................20

Table 4-4. Degree of Consideration of Reactor Physics Safety............................................................220

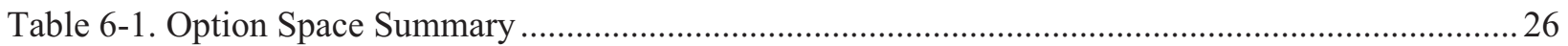




\section{ACRONYMS}

\begin{tabular}{|c|c|}
\hline $\begin{array}{l}\text { a.k.a. } \\
\text { BWR }\end{array}$ & $\begin{array}{l}\text { also known as } \\
\text { Boiling Water Reactor }\end{array}$ \\
\hline $\mathrm{CR}$ & transuranic conversion ratio, production of TRU/destruction of TRU \\
\hline $\mathrm{D}$ & Deuterium \\
\hline DU & Depleted uranium \\
\hline EU & Enriched uranium \\
\hline FCRD & Fuel Cycle Research and Development \\
\hline FFH & Fusion-fission hybrid \\
\hline FLIBE & Fluorine-lithium-beryllium salt \\
\hline FTE & Full time equivalents of personnel \\
\hline GWe & Gigawatt electric \\
\hline HLW & High-level waste \\
\hline HTGR & High Temperature Gas Reactor \\
\hline $\mathrm{HM}$ & Heavy metal \\
\hline $\mathrm{ICF}$ & Inertial confinement fusion \\
\hline IMF & Inert matrix fuel \\
\hline LLW & Low-level waste \\
\hline LWR & Light water cooled reactor \\
\hline LWR-UOX & Light water cooled reactor with uranium oxide fuel \\
\hline LWR-ThOX & Light water cooled reactor with thorium oxide fuel \\
\hline MOX & Mixed Oxide \\
\hline MSR & Molten salt fueled reactor \\
\hline MWth-d/kg-iHM & Megawatt days (thermal) per kilogram of initial heavy metal \\
\hline NGNP & Next Generation Nuclear Plant (an HTGR project) \\
\hline NU & Natural uranium \\
\hline PWR & Pressurized Water Reactor \\
\hline $\mathrm{R} \& \mathrm{D}$ & Research \& development \\
\hline RU & Recovered uranium (irradiated and recovered during fuel processing) \\
\hline SFR & sodium cooled fast reactor \\
\hline $\mathrm{T}$ & Tritium \\
\hline TRU & Transuranic elements: $\mathrm{Np}, \mathrm{Pu}, \mathrm{Am}, \mathrm{Cm}, \mathrm{Bk}$, and $\mathrm{Cf}$ \\
\hline UOX & Uranium-dioxide \\
\hline
\end{tabular}




\section{SYSTEM ANALYSIS CAMPAIGN FILLING GAPS WITH FIVE FUEL CYCLE STUDIES}

\section{INTRODUCTION}

During FY2010, five studies were conducted of technology families' applicability to various fuel cycle strategies to fill in knowledge gaps in option space and to better understand trends and patterns. Here, a "technology family" is considered to be defined by a type of reactor and by selection of which actinides provide fuel. This report summarizes the higher-level findings; the detailed analyses and results are documented in five individual reports, as follows:

- Advanced once through with uranium fuel in fast reactors (SFR) [Kim2010],

- Advanced once through or single recycle with uranium or TRU fuel in high temperature gas cooled reactors (HTGR) [Piet2010b],

- Sustained recycle with Th/U-233 in light water reactors (LWRs) [Yun2010],

- Sustained recycle with Th/U-233 in molten salt reactors (MSR) [Gehin2010], and

- Several fuel cycle missions with Fusion-Fission Hybrid (FFH) [Halsey2010]

Each study examined how the designated technology family could serve one or more designated fuel cycle missions, filling in gaps in overall option space. Each study contains one or more illustrative cases that show how the technology family could be used to meet a fuel cycle mission, as well as broader information on the technology family such as other potential fuel cycle missions for which insufficient information was available to include with an illustrative case. None of the illustrative cases can be considered as a reference, baseline, or nominal set of parameters for judging performance; the assessments were designed to assess areas of option space and were not meant to be optimized. There is no implication that any of the cases or technology families are necessarily the best way to meet a given fuel cycle mission.

\subsection{Purpose}

The five studies were performed this year (FY 2010) to fill in knowledge gaps identified in last year's (FY 2009) Options Study.[Wigeland2009] That is, how could the designated technology families potentially provide designated fuel cycle missions. The information developed during these studies helped to inform the Phase II Options Study.[Wigeland2010] The studies were instructed to watch for overarching themes or results, including the following:

- Trends on performance as a function of fuel cycle strategy, conversion ratio (CR), etc.

- Implications on R\&D needs - not a laundry list but any commonly identified things that would enable classes of options

- Implications on discriminators that were not so visible in the Options Study or the 2010 Metric Study.[Dixon2009]

The studies were also intended to provide a common outline and content for technology family assessments and to provide recommendations on doing similar sorts of studies in the future. 


\subsection{Technology Families Studies}

Table 1-1 summarizes the cases studied in the five reports. Each technology family, as defined by the reactor component of the fuel cycle (LWR, HTGR, SFR, MSR, FFH) and the category of actinides that serve as fuel, has various motivations behind studying it. Of course, the LWR is the sole technology family used in the 104 operating U.S. nuclear electricity facilities today. The HTGR is an option for both electricity and high temperature processing. The FFH can be a step toward fusion energy. Knowledge of how the LWR, HTGR, or FFH could serve one or more fuel cycle missions is therefore quite valuable. The SFR and MSR appear to offer unique advantages to one or more fuel cycle missions and therefore require study, such as done this fiscal year.

Table 1-1. Cases Analyzed in the Five Studies.

\begin{tabular}{|c|c|c|c|c|c|c|}
\hline $\begin{array}{l}\text { Recycle } \\
\text { or not? }\end{array}$ & $\begin{array}{c}\text { What is } \\
\text { disposed? }\end{array}$ & $\begin{array}{l}\text { Light } \\
\text { Water } \\
\text { Reactor } \\
\text { (LWR) }\end{array}$ & $\begin{array}{c}\text { High } \\
\text { Temperature } \\
\text { Gas Reactor } \\
\text { (HTGR) }\end{array}$ & $\begin{array}{l}\text { Sodium Fast } \\
\text { Reactor } \\
\text { (SFR) }\end{array}$ & $\begin{array}{l}\text { Molten } \\
\text { Salt } \\
\text { Reactor } \\
\text { (MSR) }\end{array}$ & $\begin{array}{c}\text { Fusion- } \\
\text { Fission } \\
\text { Hybrid } \\
\text { (FFH) }\end{array}$ \\
\hline $\begin{array}{l}\text { Once } \\
\text { through }\end{array}$ & $\begin{array}{l}\text { Unprocessed } \\
\text { used fuel }\end{array}$ & & $\begin{array}{l}\text { Pebble bed, } \\
\text { Prismatic }\end{array}$ & Breed and burn & & $\begin{array}{l}\text { Once } \\
\text { through } \\
\text { deep-burn }\end{array}$ \\
\hline $\begin{array}{l}\text { Single } \\
\text { recycle }\end{array}$ & $\begin{array}{l}\text { RU/DU, } \\
\text { fission } \\
\text { products, } \\
\text { used fuel }\end{array}$ & & $\begin{array}{l}\text { IMF (deep- } \\
\text { burn) in } \\
\text { pebble bed or } \\
\text { prismatic }\end{array}$ & & & $\begin{array}{l}\text { Fissile fuel } \\
\text { factory }\end{array}$ \\
\hline \multirow{3}{*}{$\begin{array}{l}\text { Sustained } \\
\text { recycle }\end{array}$} & \multirow{2}{*}{$\begin{array}{l}\text { RU/DU, } \\
\text { fission } \\
\text { products, } \\
\text { and } \\
\text { processing } \\
\text { losses }\end{array}$} & & $\begin{array}{l}\text { MOX, } \\
\text { Mix of UOX } \\
\& \text { IMF (needs } \\
\text { more study) }\end{array}$ & & & $\begin{array}{l}\text { Dedicated } \\
\text { waste burner }\end{array}$ \\
\hline & & $\begin{array}{l}\text { Th/U- } \\
\text { MOX }\end{array}$ & & & $\begin{array}{l}\text { Th/U } \\
\text { denatured, } \\
\text { Th/U with } \\
\text { periodic } \\
\text { salt } \\
\text { disposal }\end{array}$ & \\
\hline & $\begin{array}{l}\text { Fission } \\
\text { products and } \\
\text { processing } \\
\text { losses }\end{array}$ & & & & & \\
\hline \multicolumn{7}{|c|}{$\begin{array}{l}\text { The categorization of the MSR is not as straightforward as first believed. The denatured Th/U concept } \\
\text { if started with enriched U235 really has no separation other than fission product gas removal and is } \\
\text { eventually discarded; it could considered "once through." Th/U with periodic salt disposal } \\
\text { deliberately discarded the thorium/retained fission products/carrier salt; it is classified as sustained or } \\
\text { full recycle, with the discarded thorium considered process losses. }\end{array}$} \\
\hline
\end{tabular}

\subsection{Schedule}

The schedule during FY 2010 is informative because it clarifies what can be conducted with 0.5-FTE level of efforts during a single fiscal year. However, the true cost of each study (if done from "scratch") would be several times higher as each study leveraged other past and current efforts. 
November 19-20, 2009 - System Analysis Working Group meeting. This included kick-off presentations on the five technology families. There was discussion as to the purpose of the five studies, individually and collectively.

February 9-10, 2010 - The study leads met to discuss a common approach, common report outline, and agenda, including how far it was possible to analyze in each of the major performance areas of waste management, uranium utilization, proliferation resistance and physical protection, safety, and economics. The concept of identifying "illustrative cases" within each technology family was further developed.

March 31, 2010 - Draft reports from each study were submitted. These defined which illustrative cases were being analyzed and why.

April 20-21, 2010 - System Analysis Working Group meeting. This reviewed progress made and which illustrative cases were to be studied in more detail during the rest of the fiscal year. Discussions were held on how the illustrative cases mapped into evolving definitions of the DOE fuel cycle strategies of once through, modified open, and full recycle. (Those definitions subsequently changed.) Feedback was received on the purpose of the individual studies and the set of studies collectively. Study leads were directed to:

- Think about how the concept studies can contribute to the boundaries/limit studies, a parallel FY 2010 activity looking at the limits of possible performance among fuel cycle option space.

- Collect high impact technology development needs, items that are common among several options.

- Make sure they are doing apples/apples comparison (example is if you can create high actinide containing blankets for FFH you can also create high-actinide containing targets for reactors)

- Try to identify "hidden" issues.

- Go beyond reactor physics.

- Do not create new proliferation metrics

August 23, 2010 - Final reports from each study were submitted.

September 1-2, 2010 - System Analysis Working Group meeting. This included presentations of the major results of each individual study and preliminary discussions of the implications of the five studies collectively.

September 20, 2010 - Draft of this report.

November 19, 2010 - Final version of this report. 
This page intentionally left blank. 


\section{THE COMMON REPORT TEMPLATE AND ITS VALUE}

Because the FY 2010 scope included five studies with the same objective, but different targets of inquiry, we considered having a common report outline. During iteration, we realized that a common outline would provide more than just an aid to writing. As one study realized the need to explore a particular topic, coordination among the studies posed the question of whether the other studies should explore the same topic for their technology families. In short, the common template helped identify gaps in the body of previous work and to allocate resources for the FY 2010 assessments.

Table 2-1 lists the topics in the common report template. No individual study was able to include all topics listed due to lack of previous work to harvest and constraints on resources for new analyses.

Table 2-1. Common Report Template.

\begin{tabular}{|l|}
\hline 1. Introduction \\
How the option compares to the status quo (once through LWR) \\
Describe the option space for the technology family \\
Which fuel cycle strategies can be considered for the technology family? \\
2. Background and Past Work \\
What parts of option space have been explored and why? \\
What distinguishes the technology Family? \\
Technology readiness \\
1. Description of Illustrative Concepts within Technology Family \\
Key parameters for illustrative concepts \\
Information on deployment (if any) \\
4. Assessment of Illustrative Concepts within Technology Family \\
4.2 Used Fuel Disposal, Separations, and Waste Management \\
4.3 Resource Sustainability \\
4.4 Proliferation Resistance and Physical Protection \\
4.5 Economics \\
4.6 Safety \\
\hline 5. Conclusions and Future Work
\end{tabular}

Note that the contents of the first two chapters induced examination of just what defined and characterized a technology family and why. This was often the most creative part of the effort, considering whether the past studies in a technology family did or did not represent the full range of options as the range of fuel cycle strategies is understood today. Often, the FY 2010 assessments in these chapters could go no further than identify potential areas of option space, with little quantitative assessments in later chapters, due to resource constraints.

One example is a truly minimum-waste molten salt. Past MSR studies planned on routinely discarding a fraction of coolant/fuel salt, even if sustained recycle is the objective. This impacts actinide utilization and waste management. As fuel cycle objectives are understood today, there would be more emphasis on not having to routinely discard the salt, with corresponding R\&D needs. The MSR report could only mention this possibility, not quantitatively analyze it.

Another example is sustained recycle with an HTGR. The HTGR has been studied in the once through and single recycle strategies and these form the basis of illustrative concepts in the HTGR study. However, sustained recycle in an HTGR should be possible, as it is for an LWR, but quantitative analysis of this possibility awaits future work. 
This page intentionally left blank. 


\section{ASSESSING HOW AN OPTION CAN SERVE A FUEL CYCLE}

The five individual studies examined how a given technology family could serve one or more fuel cycle missions. By considering the set of studies in this report, we can draw broader observations and conclusions. Therefore, this chapter pertains to higher-level results and the next chapter pertains to technology performance trends among the technology families. In this chapter, we discuss cautions and limitations, how can a technology originally focused on one fuel cycle mission be adapted to another, how a reactor built for one fuel cycle mission could be adapted later to another fuel cycle mission, and how well can technology family potential be captured by discrete sets of parameters.

\subsection{Cautions and Limitations}

Each study contains one or more illustrative cases that show how the technology family could be used to meet a fuel cycle mission, as well as broader information on the technology family such as other potential fuel cycle missions for which insufficient information was available to include with an illustrative case.

The primary intent of this work was to develop an initial understanding of how the technology families worked and their potential to varying fuel cycle approaches. If warranted, additional resources can be applied to selected families to perform the in-depth analyses necessary to quantitatively assess specific cases.

Each current study necessarily started with an examination of past and current work. This led to defining illustrative cases that generally were built on past or current work, few "started from scratch". The past can be almost as much as a half-century ago, e.g., MSR studies done with different objectives than modern fuel cycles.

\subsection{Adapting a Technology Family to a New Fuel Cycle Mission}

Design parameters and therefore fuel cycle performance depend on both the technology family and the fuel cycle approach. It is important to understand how the underlying characteristics of a technology family interact with fuel cycle approaches.

First, consider that the primary technical disciplines that dominate design in the studies differ, making it difficult to give a single process diagram that would show how a technology family could be adapted to a new fuel cycle mission. Dave Petti (INL, NGNP technical lead) has remarked that

- LWR is the thermal hydraulists' reactor.

- MSR is the chemical engineers' reactor.

- HTGR is the material scientists' reactor.

- $\quad$ SFR is the reactor physicists' reactor.

To which we add the following:

- The fusion-fission hybrid is the plasma physicists' reactor.

Thus, the relative importance of technical disciplines and issues varies among each technology family. For example, adapting the MSR to a new fuel cycle mission immediately gets into the chemical engineering options for doing different things with the existing salt candidate and/or examination of different salt options. But, the heat transfer problems may not change much. Consideration of new fuel cycle missions for the HTGR opens the question of whether the hard-won achievements with TRISO fuel 
coating (developed for the once through fuel cycle) might be best set aside; whether other materials and coatings could conceivably provide better performance for other fuel cycle approaches. For example, General Atomics' current $\mathrm{EM}^{2}$ concept instead uses vented fuel to maximize uranium utilization.

When a technology family is considered for use in a new fuel cycle mission, fuel cycle performance characteristics are dependent on both the design choices and the fuel cycle approach. For example, the use of the sodium-cooled fast reactor to provide recycle in either breeder or burner mode has been studied for decades, but the SFR could be considered for once-through fuel cycle with the physical reactor design and fuel management parameters changed. In addition, the sustained recycle of Th/U-233 in LWR could be achieved with a heterogeneous assembly and derated power density. Therefore, it may or may not be adjustable for other fuel cycle missions although a reactor intended for one fuel cycle mission is built. Simple parameter adjustment in applying a technology family to a new fuel cycle mission should be avoided and, if observed, the results viewed with caution.

The simplest adaptation of a technology from one fuel cycle strategy to another does not necessarily produce the "best" implementation of that strategy. These are not just smooth transitions; they can be step function changes.

\subsection{Adapting a Reactor Built for One Fuel Cycle to Another}

As new reactors are built to provide electricity, can they only serve a single fuel cycle mission (that envisioned when they are built)? If so, the selection of each new power reactor tends to constrain the national fuel cycle for the reactor's lifetime. If instead, reactors have some adaptability to serve multiple fuel cycle missions; then, more flexibility is passed to future generations if circumstances and priorities change. See Table 3-1 for some examples. More work is warranted on this topic.

One sometimes has to get into details to understand how adaptable a reactor might be. For example, it might appear that a fusion-fission hybrid (FFH) could be easily changed from the waste burner mission to fuel factory by simply changing the contents of a fissile zone module. However, the optimal neutron energy spectrum for each mission differs; waste burner probably benefits from higher energy neutrons closer to the fusion plasma; fuel breeding of U-233 to Th-233 can be done with thermalized neutrons. Thus, the appropriate location from the fusion plasma source differs, not simply the contents of a fissile zone module. The amount of heat created per volume differs; hence the design of the coolant system serving the fissile zone differs. 
Table 3-1. Adaptability of a Reactor Built for One Fuel Cycle to Serve a Different Fuel Cycle.

\begin{tabular}{|c|c|c|c|c|c|}
\hline & $\begin{array}{c}\text { Light Water } \\
\text { Reactor (LWR) }\end{array}$ & $\begin{array}{c}\text { High } \\
\text { Temperature } \\
\text { Gas Reactor } \\
\text { (HTGR) }\end{array}$ & $\begin{array}{l}\text { Sodium Fast } \\
\text { Reactor } \\
\text { (SFR) }\end{array}$ & $\begin{array}{l}\text { Molten Salt } \\
\text { Reactor } \\
\text { (MSR) }\end{array}$ & $\begin{array}{c}\text { Fusion-Fission } \\
\text { Hybrid } \\
\text { (FFH) }\end{array}$ \\
\hline $\begin{array}{l}\text { Fuel cycle } \\
\text { mission that } \\
\text { has dominated } \\
\text { technology } \\
\text { family } \\
\text { development }\end{array}$ & Once through & Once through & $\begin{array}{l}\text { Sustained } \\
\text { recycle with } \\
\text { U/Pu fuel } \\
\text { MA burner } \\
\text { with U/TRU- } \\
\text { based fuel }\end{array}$ & $\begin{array}{l}\text { Sustained } \\
\text { recycle with } \\
\text { Th/U-233 fuel }\end{array}$ & $\begin{array}{l}\text { Waste burner } \\
\text { of TRU not } \\
\text { consumed in } \\
\text { fission reactors } \\
\text { - tend to want } \\
\text { very high } \\
\text { energy } \\
\text { neutrons }\end{array}$ \\
\hline $\begin{array}{l}\text { Alternative } \\
\text { fuel cycles for } \\
\text { which a built } \\
\text { reactor for the } \\
\text { original fuel } \\
\text { cycle might be } \\
\text { easily adjusted }\end{array}$ & $\begin{array}{l}\text { TRU-based } \\
\text { IMF/deep-burn } \\
\text { single recycle } \\
\text { U/TRU-based } \\
\text { sustained } \\
\text { recycle }\end{array}$ & $\begin{array}{l}\text { TRU-based } \\
\text { IMF/deep-burn } \\
\text { single recycle } \\
\text { of feed from } \\
\text { used LWR fuel }\end{array}$ & & $\begin{array}{l}\text { Once through } \\
\text { based on } \\
\text { enriched } \\
\text { uranium }\end{array}$ & \\
\hline $\begin{array}{l}\text { Alternative } \\
\text { fuel cycles for } \\
\text { which } \\
\text { adaptability of } \\
\text { a built reactor } \\
\text { is unclear }\end{array}$ & $\begin{array}{l}\mathrm{Th} / \mathrm{U}-233 \\
\text { because the } \\
\text { spectrum } \\
\text { should be } \\
\text { much harder }\end{array}$ & $\begin{array}{l}\text { U/TRU-based } \\
\text { sustained } \\
\text { recycle - needs } \\
\text { either a } \\
\text { practical and } \\
\text { economic way } \\
\text { to separate } \\
\text { TRISO fuel or } \\
\text { a new fuel } \\
\text { coating } \\
\text { approach }\end{array}$ & & $\begin{array}{l}\text { TRU-based } \\
\text { sustained } \\
\text { recycle for } \\
\text { waste } \\
\text { minimization }\end{array}$ & \\
\hline $\begin{array}{l}\text { Alternative } \\
\text { fuel cycles for } \\
\text { which a built } \\
\text { reactor would } \\
\text { be difficult or } \\
\text { impossible to } \\
\text { adjust to, while } \\
\text { maintaining } \\
\text { reasonable } \\
\text { performance }\end{array}$ & & & $\begin{array}{l}\text { Once through } \\
\text { with uranium } \\
\text { fuel - the } \\
\text { physical } \\
\text { dimensions of } \\
\text { a reactor vessel } \\
\text { would have to } \\
\text { be changed to } \\
\text { allow "breed } \\
\text { and burn" }\end{array}$ & & $\begin{array}{l}\text { Fuel factory } \\
\text { Once through } \\
\text { deep-burn }\end{array}$ \\
\hline
\end{tabular}

\subsection{Using Data to Support a Decision}

Ultimately, system analyses of technology families and fuel cycle missions are intended to help make decisions. Previously in this chapter, two adaptability issues were raised and discussed. In this subsection, we tackle the broader questions of using data to support a decision in two ways.

The first is the difference among data, information, and knowledge. One classification scheme is as follows:[Ackoff1989] 
1. Data: symbols

2. Information: data that are processed to be useful; provides answers to "who", "what", "where", and "when" questions

3. Knowledge: application of data and information; answers "how" questions

4. Understanding: appreciation of "why"

5. Wisdom: evaluated understanding.

The individual five study reports contain some of each of the above (data to wisdom), but are more heavily weighted toward data and information. Each has considerable amounts of data, given understanding of the relationships among data, translates the data into "information." These reports emphasized understanding how the individual technology families work in the illustrative fuel cycles and the relationship between their technical characteristics and potential performance.

This report attempts to go further in understanding the patterns, by studying the five studies (and indeed past work) as a whole. In this report, we sought understanding common patterns across multiple technology families. In some instances, the underlying principles are made more clear, such as what happens to long-term radioactivity as uranium utilization increases. So, the authors hope that the report contributes to knowledge and perhaps even a bit more wisdom.

Bellinger, Castro, and Mills have adapted the Ackoff scheme into the following Figure 3-1, showing how connecting and understanding over larger and broader parts of option space assists in moving from data to information to knowledge to wisdom.

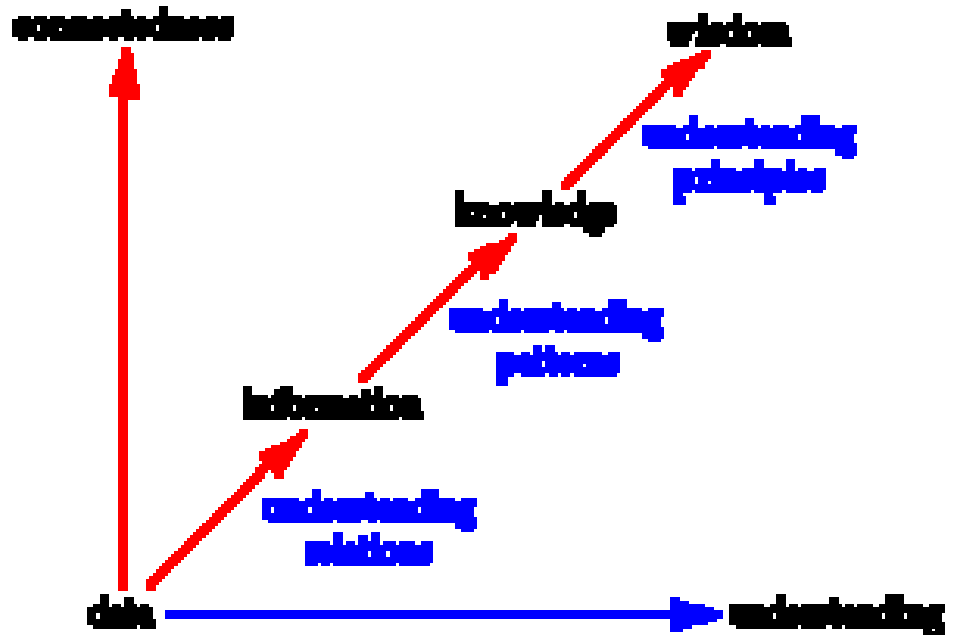

Figure 3-1. Relationship among data, information, knowledge, and wisdom.

The second way of approaching the data-to-decision challenge is sometimes called reductionist versus holistic. "Reductionist" emphasizes breaking a complex topic into smaller and smaller pieces so that each can be easily understood. "Holistic" emphases looking at a complex topic as a whole and integrating and reintegrating information into updated understanding. Both have appropriate uses.

When one is attempting to examine a large number of pieces of information, one can be overwhelmed. Since all of us must be "cognitive misers" on occasion - for example when faced with a hundred new e- 
mails - one must filter the mass of information. This has been called "selective inattention". MIT Professor David J. Rose wrote in his book, "Learning about Energy" about "selective inattention"

"Faced with such a wealth and breadth of information, views, goals, and paradoxes, the leader, company, government agency, or other group molds some particular subset of the whole into a logical framework, then acts as if that construction were the whole of it. What is inside - nuclear power or conservation or national security - is the key to all, and what lies outside becomes either selectively ignored or recast to support the central theme. To be sure, daily life demands selective inattention, or else we would overwhelm ourselves with remembered trivia, but in dealing with naturally extensive topics like energy, it is to be guarded against. Holistic, extensive thinking and reintegration stand in contrast to selective inattention implicit in disciplinary reductionism or bureaucratic fragmentation, in which intellectual, social, or technological sectors become subdivided for ease in manipulation or special understanding."[Rose1986] 
This page intentionally left blank. 


\section{OBSERVING PERFORMANCE TRENDS AMONG FAMILIES}

This chapter discusses performance trends among families in the areas of waste management, uranium and thorium utilization, proliferation resistance and physical protection, safety, and economics.

One broad observation is that there are factors shaping illustrative cases within each technology class that are not reflected in higher-level performance measures for waste management, uranium and thorium utilization, proliferation resistance and physical protection, safety, and economics. That is, the reason that concept developers have set design parameters in past work is sometimes not obvious if one considers only the existing higher-level metrics. They considered constraints or objectives not appearing in higherlevel metrics. Thus, one could in principle achieve high performance in fuel cycle metrics if these selfimposed metrics were ignored, but have an unworkable system. An example is that reactor physics safety considerations are accounted for to varying degrees in early concept development. It is therefore questionable to compare results for a case in which all the various reactor physics constraints such as negative power coefficients have been analyzed and met versus results for other cases in which one or more such constraints have not been studied.

\subsection{Waste Management}

In general waste management performance depends primarily on the following:

- Fuel cycle mission or strategy

$\circ$ What, if anything, is recycled

- Which minor actinides (Np, Am, Cm, Bk, Cf) are included with Pu

- Th-U fuel cycle versus U-Pu

- Fuel burnup - for once through or single recycle

- Losses of TRU into waste streams - for sustained recycle

- Presence or absence of an external supply of neutrons

- If used fuel is mechanically processed to separate fuel meat from coating, cladding, and other incore structure.

\subsubsection{Radiotoxicity}

Figure 4-1 shows five patterns for the radiotoxicity inventory as a function of time - for cases that existed before the current study.

1. Once through

2. Single recycle with moderate CR, e.g., "MOX"

3. Single recycle with low CR, e.g., "IMF" or "deep burn"

4. Sustained recycle with moderate CR (burner)

5. Sustained recycle with high CR (breeder) 


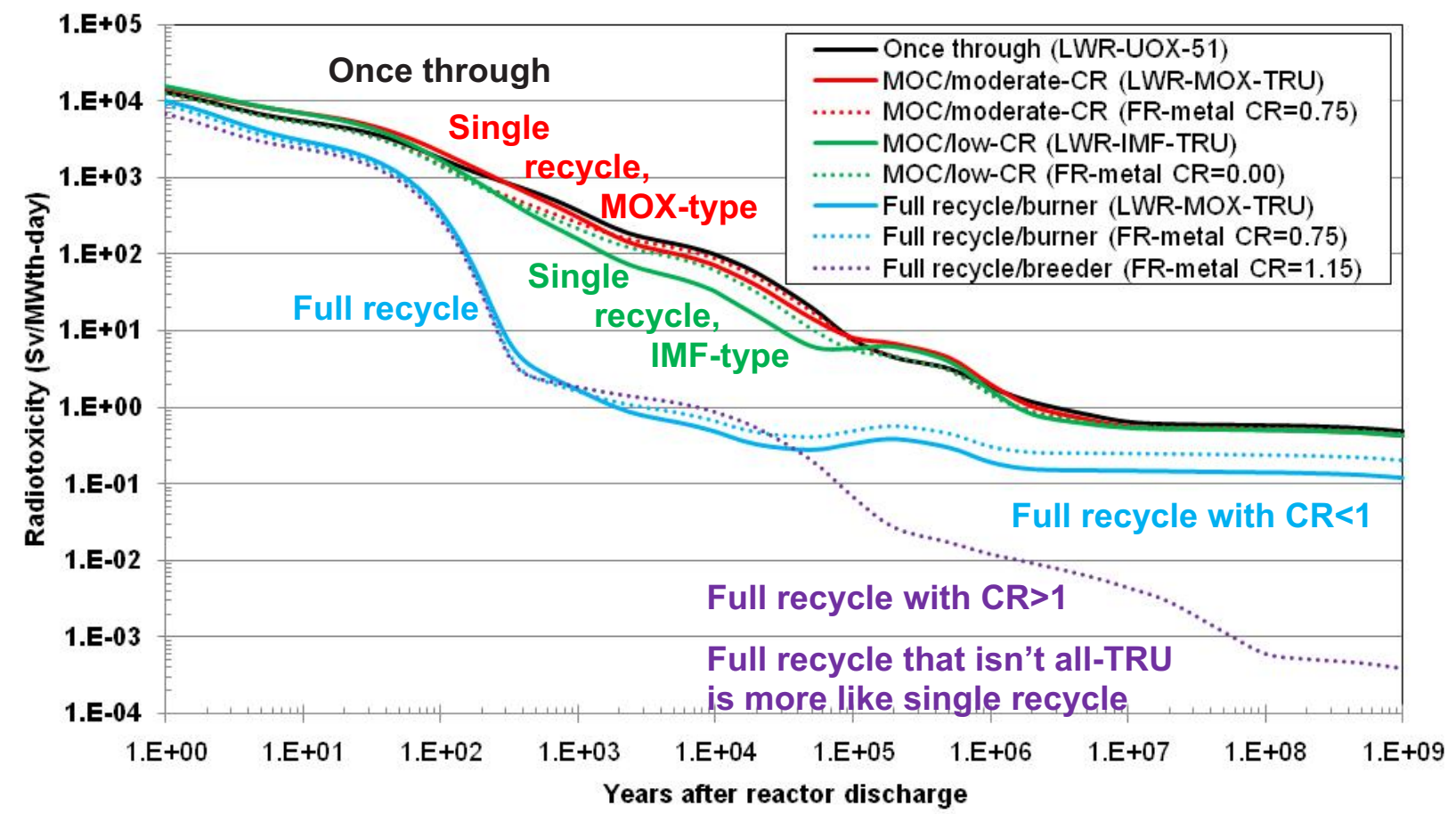

Figure 4-1. Radiotoxicity for a wide range of uranium-TRU fuel cycles.

It is not the pure fission reactor per se that matters but rather the fuel cycle strategy and the transuranic conversion ratio (CR). A single recycle provides less than an order of magnitude change to the radiotoxicity profile from once through: relatively larger change if using IMF/deep-burn (because there is more consumption of TRU in the single recycle) and relatively smaller change if using MOX. Note that $\mathrm{IMF}$ has $\mathrm{CR} \sim 0$; therefore, the lower the $\mathrm{CR}$, the larger the radiotoxicity reduction in single-recycle options versus once through.

Full or sustained recycle can provide orders of magnitude reduction in the time period of 100 to 100,000 years, almost regardless of the reactor. In this time period, the issues are whether all transuranic elements are recycled and the loss fraction of TRU into waste streams. The orders of magnitude reduction versus once through can continue beyond 100,000 if all recovered uranium is itself recycled and consumed; this requires a breeder reactor $(\mathrm{CR}>1)$.

Now, consider the cases in this study and how they add to our knowledge of radiotoxicity patterns.

HTGR deep burn is not significantly different than LWR-IMF. If both approaches are credible from the materials and void coefficient standpoint, the transmutation performance is similar and thus the radiotoxicity results are essentially the same.

There are not sufficient isotope-specific data for the Fusion-Fission Hybrid cases to defendably calculate radiotoxicity, e.g., Tc99 and Am241 is not in the preliminary dataset. If indeed very high, e.g., 99\%, of the actinides can be fissioned in a FFH, the preliminary data shows that the radiotoxicity is always within an order of magnitude of the sustained recycle/breeder curve in Figure 4-1 - unsurprising since in both cases $99 \%$ of the actinides are consumed.

Figure 4-2 shows how the "breed and burn" cases (once through fast reactors) that use the once-through fuel cycle compare with other fast reactor cases and with LWR UOX. Unsurprisingly, the six breed and burn follow the same pattern. From 1,000 to 100,000 years, their radiotoxicity is higher than oncethrough LWR UOX because they have made more Pu-239 than LWR UOX but not consumed it. Pu-239 
(2.4e4 yr) has a shorter halflife than $\mathrm{U} 235$ (7.0e8 $\mathrm{yr}$ ) and $\mathrm{U} 238(4.5 \mathrm{e} 9 \mathrm{yr})$, so it is disadvantageous to make it without consuming most of it, as is done with breed and burn (once through) fast reactors. In contrast, the two sustained recycle fast reactors (both burner and breeder cases) in Figure 4-2 do show markedly lower radiotoxicity. Even a single fast reactor recycle with low CR (dotted green line) has lower radiotoxicity in the 1,000 to 100,000 year time period.

Beyond about 100,000 years, the breed and burn cases have lower radiotoxicity than LWR UOX because they have less residual uranium. That is, consistent with other patterns, as less uranium is required in a fuel cycle, the very long radioactivity is lower; these breed and burn cases have $1 \%$ to $30 \%$ uranium utilization (versus $<1 \%$ for LWR UOX) and therefore their very long-term radiotoxicity ranges from about the same as LWR UOX to an order of magnitude lower.

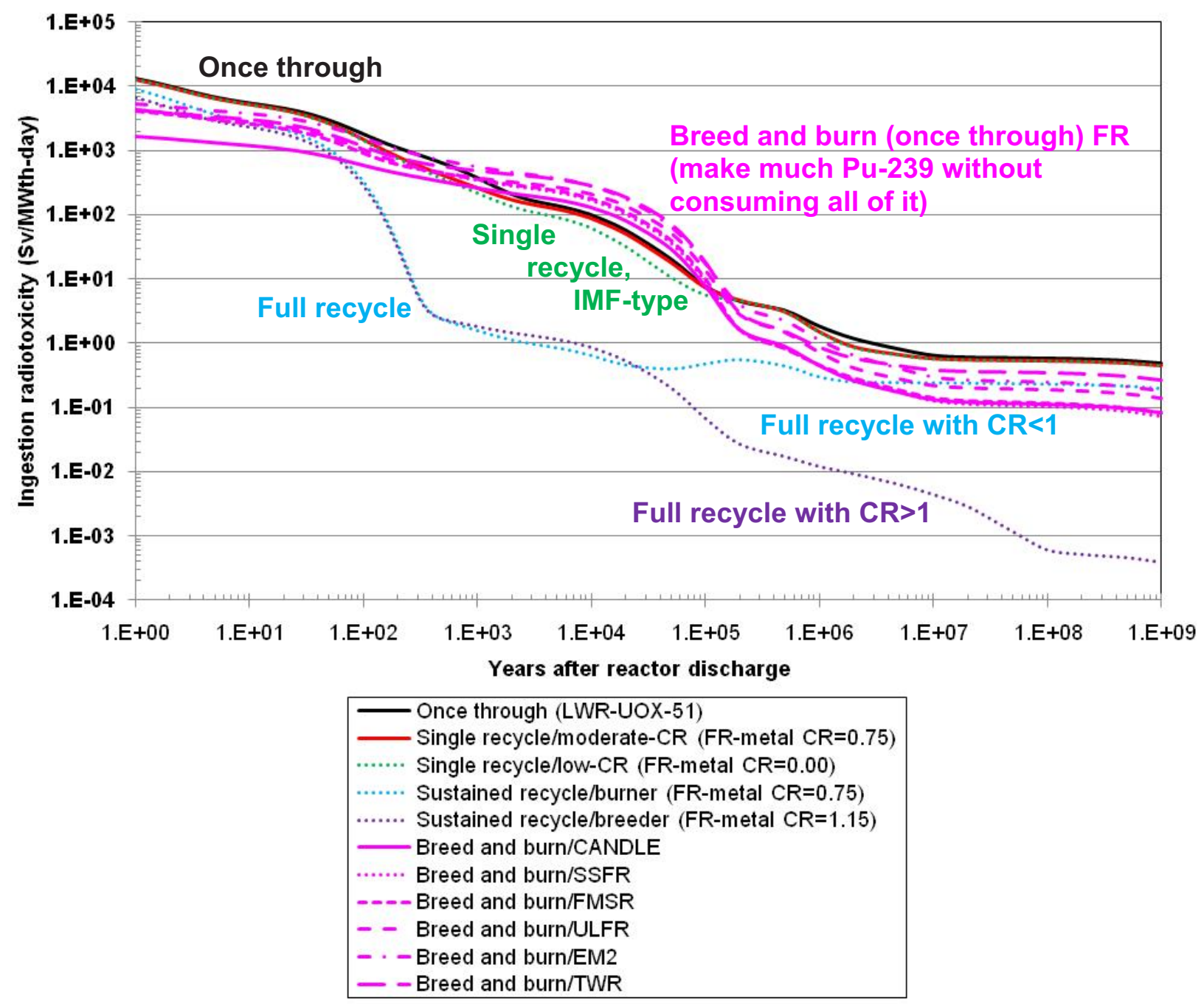

Figure 4-2. Radiotoxicity for breed and burn (once through) fast reactors, much Pu-239 is made without consuming "all" of it.

We now turn to the two thorium cases among the five studies, LWR and MSR. Although both concepts are intended to eventually serve as sustained recycle, we currently only have preliminary data in which the fresh fuel is Th-232/U-233 and used fuel is discarded. Thus, the discharged Th-232/U-233 LWR fuel is simply discarded. In the current MSR data, salt is introduced and disposed after 15 years. In both cases, much U-233 is made (or initially charged into the reactor) but most of it is not consumed. U-233 
(1.6e $5 \mathrm{yr}$ ) has a shorter halflife than U-235 and U-238, so it is disadvantageous from a radiotoxicity standpoint to make it without consuming it. Figure 4-3 shows these "single charge and dispose" cases. The "hump" with U-233 occurs slightly later than the Pu-239-induced increase in Figure 4-2 because the $\mathrm{U}-233$ halflife is longer than $\mathrm{Pu}-239$ and therefore it takes longer for U-233 progeny to accumulate. The peak radiotoxicity in these cases stems from U-233 and its progeny Th-229, Ra225, and Ac225. (Th-229 dominates.) As with the breed and burn cases in Figure 4-2, the very long-term radiotoxicity is lower than LWR UOX because the uranium utilization is improved relative to LWR-UOX, LWR-IMF, and LWR-MOX.

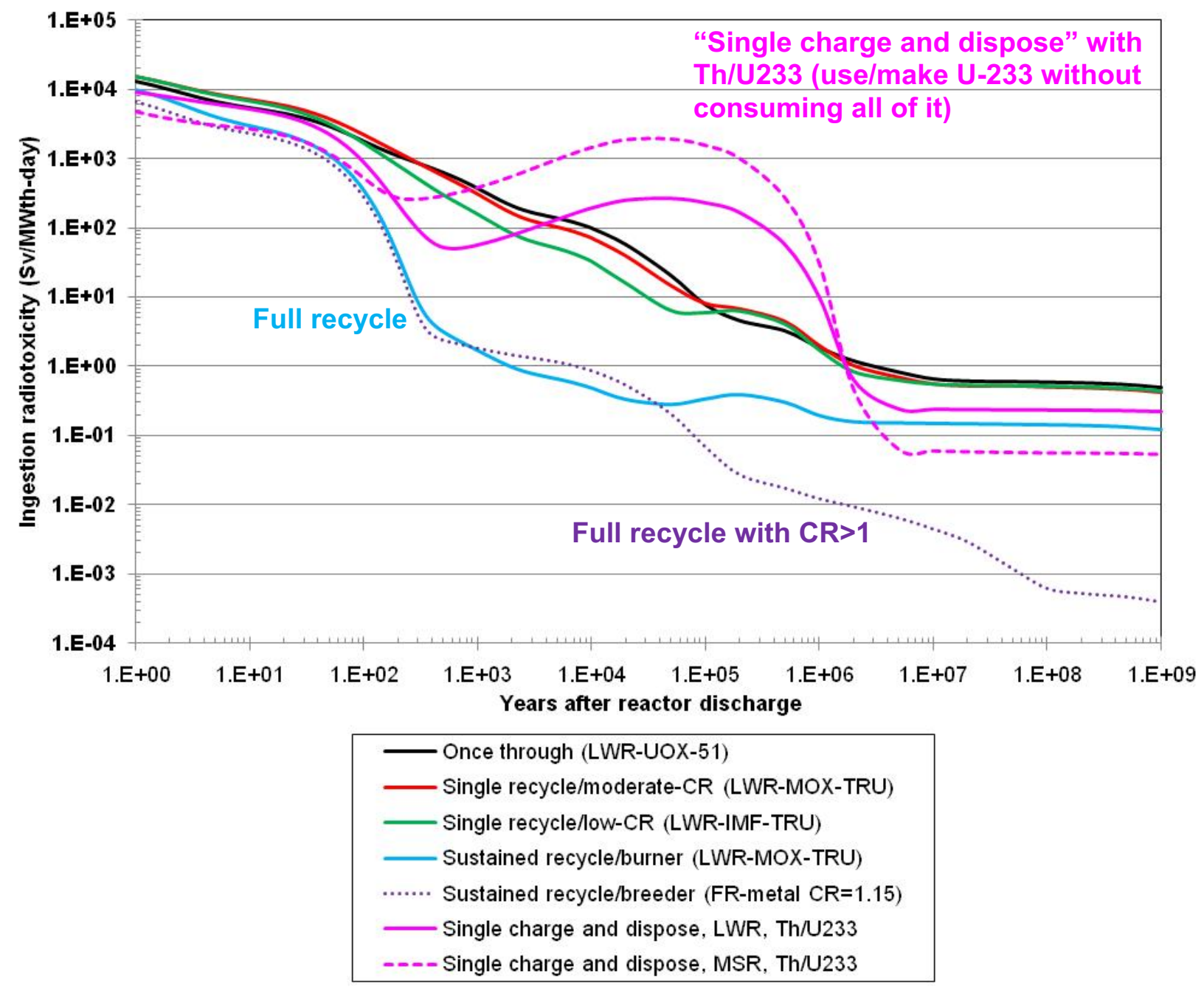

Figure 4-3. Radiotoxicity for "single charge and dispose" reactors charged with Th/U233; much U-233 is used without consuming "all" of it.

The above analysis leads to two observations. First, there are two ways to achieve orders of magnitude of radiotoxicity reduction relative to once through: full/sustained recycle of all TRU (with less than 1\% TRU loss to waste) and an external supply of neutrons such as from a FFH (if $99 \%$ of the actinides are consumed). Second, fuel cycles that make Pu-239 and U-233 without consuming most of it can have higher radiotoxicity (1,000 to 100,000 years) than U-235 based systems. However, in such Pu-239 and U-233 driven systems, the very long-term radiotoxicity appears lower than U-235 based systems because there is less residual uranium in waste. True sustained recycle with U-233 requires more study. 


\subsubsection{Non-fuel contribution to waste}

The above figure only addresses "fuel meat", which can be a minority of the mass routinely removed from a reactor during refueling. Table 4-1 helps illustrate the potential importance of separating fuel meat (kg-iHM/assembly) from other in-core material (kg-total/assembly). The ratio of total mass to fuel meat mass varies from 1.4 to over 100. Even if the fuel meat (uranium, TRU) is not to be recycled, there can be significant reduction in total mass and volume if the non-fuel materials can be separated from the fuel meat.

Table 4-1. Mass of Fuel Assemblies in Various Options.

\begin{tabular}{|c|c|c|c|}
\hline & $\begin{array}{l}\text { kg-iHM/ } \\
\text { assembly }\end{array}$ & $\begin{array}{l}\text { kg-total/ } \\
\text { assembly }\end{array}$ & $\begin{array}{l}\text { Ratio of total } \\
\text { mass to iHM }\end{array}$ \\
\hline Once through PWR UO2 & 461.3 & 657.9 & 1.4 \\
\hline Single or sustained recycle LWR MOX & 461.3 & 657.9 & 1.4 \\
\hline Single or sustained recycle LWR IMF-Pu & 37.2 & 530.9 & 14.3 \\
\hline Single or sustained recycle LWR IMF-NpPuAm & 42.7 & 580.8 & 13.6 \\
\hline Single or sustained recycle LWR IMF-TRU & 42.5 & 578.8 & 13.6 \\
\hline Once through BWR UO2 & 183.3 & 319.9 & 1.7 \\
\hline Single or sustained recycle $\mathrm{Th} / \mathrm{U}-233$ & 770.3 & 909.2 & 1.2 \\
\hline Once through SFR - SSFR & 435.4 & 891.8 & 2.0 \\
\hline \multirow[t]{2}{*}{ Once through SFR - ULFR } & 471.3 & 881.0 & 1.9 \\
\hline & $\begin{array}{l}\mathrm{kg}-\mathrm{iHM} / \\
\text { assembly }\end{array}$ & $\begin{array}{l}\text { kg-total/ } \\
\text { assembly }\end{array}$ & $\begin{array}{l}\text { Ratio of total } \\
\text { mass to iHM }\end{array}$ \\
\hline Sustained recycle FR metal $\mathrm{CR}=0.00$ & 29.7 & 349.7 & 11.8 \\
\hline Sustained recycle FR metal $\mathrm{CR}=0.25$ & 44.9 & 342.8 & 7.6 \\
\hline Sustained recycle FR metal $\mathrm{CR}=0.50$ & 69.9 & 366.1 & 5.2 \\
\hline Sustained recycle FR metal $\mathrm{CR}=0.75$ & 97.7 & 411.5 & 4.2 \\
\hline Sustained recycle FR metal $\mathrm{CR}=1.00$ & 114.1 & 446.1 & 3.9 \\
\hline Sustained recycle FR oxide CR $=0.00$ & 37.7 & 264.9 & 7.0 \\
\hline Sustained recycle FR oxide $\mathrm{CR}=0.25$ & 60.6 & 335.6 & 5.5 \\
\hline Sustained recycle FR oxide $\mathrm{CR}=0.50$ & 91.9 & 426.1 & 4.6 \\
\hline Sustained recycle FR oxide $\mathrm{CR}=0.75$ & 126.0 & 483.2 & 3.8 \\
\hline \multirow[t]{2}{*}{ Sustained recycle FR oxide $\mathrm{CR}=1.00$} & 148.6 & 540.0 & 3.6 \\
\hline & $\begin{array}{r}\text { kg-iHM/ } \\
\text { element }\end{array}$ & $\begin{array}{r}\text { kg-total/ } \\
\text { element }\end{array}$ & $\begin{array}{l}\text { Ratio of total } \\
\text { mass to iHM }\end{array}$ \\
\hline Once through HTGR-UO2 prismatic & 7.2 & 134.4 & 18.6 \\
\hline \multirow[t]{2}{*}{ Single recycle HTGR-IMF prismatic } & 1.2 & 126.9 & 102.1 \\
\hline & $\begin{array}{l}\text { kg-iHM/ } \\
\text { pebble }\end{array}$ & $\begin{array}{c}\text { kg-total/ } \\
\text { pebble }\end{array}$ & $\begin{array}{l}\text { Ratio of total } \\
\text { mass to iHM }\end{array}$ \\
\hline Once through HTGR-UO2 pebble bed & 0.011 & 0.2 & 19.9 \\
\hline \multirow[t]{2}{*}{ Single recycle HTGR-IMF pebble bed } & 0.002 & 0.2 & 98.5 \\
\hline & $\begin{array}{l}\mathrm{kg}-\mathrm{iHM} / \\
\text { reactor }\end{array}$ & $\begin{array}{l}\mathrm{kg} \text {-salt/ } \\
\text { reactor }\end{array}$ & $\begin{array}{l}\text { Ratio of total } \\
\text { mass to iHM }\end{array}$ \\
\hline Sustained recycle MSR & 69,600 & 149,300 & 2.1 \\
\hline
\end{tabular}

\subsection{Uranium and Thorium Resource Utilization}

There are two types of nuclear fuel - fissile isotopes and fertile isotopes. Fissile isotopes more readily fission. All pure fission nuclear fuel cycles must start with fissile isotopes. (Hybrid systems involving 
fusion or accelerator-driven systems that provide external energy avoid this constraint.) There is only one fissile isotope found in nature, U-235. Unfortunately, it is only $0.7 \%$ of natural uranium. There are only two fertile isotopes found in nature, U-238 and Th-232. U-238 is the other $99.3 \%$ of natural uranium. Th-232 is $100 \%$ of natural thorium.

So, all pure fission fuel cycles must start with use of the fissile portion of uranium (U-235). More fissile material can be made from fertile material by the fertile material absorbing neutrons in a nuclear reactor. If U-238 absorbs a neutron, it makes fissile Pu-239. If Th-232 absorbs a neutron, it makes fissile U-233. So, all fuel cycles can be classified as driven by U-235, Pu-239, U-233, or an external energy source (fusion or accelerators).

In a thermal neutron spectrum, the neutron capture probability (cross section) of Th-232 is three times that of U-238; thus, thorium provides a higher conversion to fissile material. In a fast neutron spectrum, the neutron capture probability of Th-232 and U-238 are about the same. One must also look at the average number of neutrons (called eta) produced when U-233 and Pu-239 absorb neutrons, considering how many lead to neutron capture (undesirably making fissile material back into fertile) and how many lead to fission. In a thermal neutron spectrum, eta for U-233 is within $20 \%$ higher than for Pu-239 (either way, depending on details). In a fast neutron spectrum, eta for U-233 and Pu-239 are about the same. Thus, from these perspectives, the U-233 fuel cycle is relatively more attractive than Pu- 239 fuel in a thermal spectrum than a fast spectrum.

These considerations (neutron capture, eta) explain why there has been more study of U-233 in a thermal spectrum than a fast spectrum.

Table 4-2 summarizes the range of uranium and thorium resource utilization possible in different systems, in terms of thermal energy released versus total theoretical energy content if entirely fissioned. 
Table 4-2. Uranium and Thorium Resource Utilization Summary

\begin{tabular}{|c|c|c|c|}
\hline & $\begin{array}{l}\text { Uranium-Plutonium Cycles } \\
\text { (U-235 or } \mathrm{Pu}-239 \text { driven) }\end{array}$ & \multicolumn{2}{|c|}{$\begin{array}{c}\text { Thorium-Uranium Cycles } \\
\text { (U-233 driven) }\end{array}$} \\
\hline & Uranium ore & Uranium ore & Thorium ore \\
\hline $\begin{array}{l}\text { Thermal } \\
\text { reactors } \\
\text { once through }\end{array}$ & $<1 \%$ & $<1 \%$ & $<2 \%$ \\
\hline \multirow{4}{*}{$\begin{array}{l}\text { Thermal } \\
\text { reactors } \\
\text { sustained } \\
\text { recycle (a) }\end{array}$} & \multirow[t]{4}{*}{$\leq 1 \%$} & $\begin{array}{l}\text { Depends on source of } \\
\text { initial U233 }\end{array}$ & $\begin{array}{l}\text { MSR with initial U233 } \\
\text { loading }-8 \%(\mathrm{~b})\end{array}$ \\
\hline & & $\begin{array}{l}\text { MSR with initial U235 } \\
\text { loading }-6 \%\end{array}$ & $\begin{array}{l}\text { MSR with initial U235 } \\
\text { loading }-8 \%(\mathrm{~b})\end{array}$ \\
\hline & & Denatured MSR - 1\% & Denatured MSR - $15 \%(b)$ \\
\hline & & $\begin{array}{l}\text { Depends on source of } \\
\text { initial U233 }\end{array}$ & $\begin{array}{l}\text { LWR-Th/U233-95\% at } \\
0.1 \% \text { loss/recycle, } 65 \% \text { at } \\
1 \% \text { loss } / \text { recycle. }\end{array}$ \\
\hline $\begin{array}{l}\text { Fast reactors } \\
\text { once through }\end{array}$ & $\begin{array}{l}\text { As high as } 30 \% \text { if very high } \\
\text { neutron fluence materials can } \\
\text { be developed }\end{array}$ & $\begin{array}{l}\text { Depends on source of } \\
\text { initial U233 }\end{array}$ & $\begin{array}{l}\text { Since enrichment is not } \\
\text { necessary, the utilization } \\
\text { is its burnup. However, } \\
\text { the attainable burnup is } \\
\text { not clear because it is } \\
\text { dependent on U-233 } \\
\text { fraction but limited by } \\
\text { excess reactivity control. }\end{array}$ \\
\hline $\begin{array}{l}\text { Fast reactors } \\
\text { sustained } \\
\text { recycle (a) }\end{array}$ & $\begin{array}{l}\text { Burners - 1\% } \\
\text { Breeders - if all TRU recycled, } \\
\text { approaches } 100 \% \text { subject to } \\
\text { processing losses, e.g., } 99 \% \text { at } \\
0.1 \% \text { loss } / \text { recycle and } 87 \% \text { at } \\
1 \% \text { loss } / \text { recycle. If only Pu is } \\
\text { recycled, the uranium } \\
\text { utilization at } 0.1 \% \text { and } 1 \% \\
\text { processing loss } / \text { recycle drops } \\
\text { to } 93 \% \text { and } 81 \% \text {. }\end{array}$ & $\begin{array}{l}\text { Depends on source of } \\
\text { initial U233 }\end{array}$ & $\begin{array}{l}\text { Breeders - if all actinides } \\
\text { recycled, should be } \\
\text { limited only by processing } \\
\text { losses }\end{array}$ \\
\hline $\begin{array}{l}\text { FFH once } \\
\text { through deep- } \\
\text { burn }\end{array}$ & $\begin{array}{l}\text { 99\% assuming very deep } \\
\text { burn-fuels can be developed or } \\
\text { mechanical re-fabrication is } \\
\text { used. }\end{array}$ & $\begin{array}{l}\text { Initial } U 233 \text { not } \\
\text { required }\end{array}$ & $\begin{array}{l}\sim 99 \% \text { assuming very } \\
\text { deep-burn fuels can be } \\
\text { developed or mechanical } \\
\text { re-fabrication is used }\end{array}$ \\
\hline $\begin{array}{l}\text { FFH waste } \\
\text { burner }\end{array}$ & \multicolumn{3}{|c|}{ Depends on the performance of the system the waste burner follows (see above). } \\
\hline $\begin{array}{l}\text { FFH fission- } \\
\text { suppressed } \\
\text { breeder }\end{array}$ & & & $\begin{array}{l}\text { If all actinides recycled, } \\
\text { should be limited only by } \\
\text { processing losses }\end{array}$ \\
\hline \multicolumn{4}{|c|}{$\begin{array}{l}\text { c. For sustained recycle, the utilization is burnup / (burnup + effective loss rate), where burnup is } \\
\text { percent of heavy metal fissioned each pass through the reactor. The effective loss rate is the } \\
\text { process loss rate of recycled actinides plus the amount of minor actinides discarded (if any). } \\
\text { d. The MSR ore utilization results are constrained because salt fuel/coolant is periodically discarded } \\
\text { in the original MSR concept and thus much thorium is discarded. That is, the effective loss rate is } \\
\text { large. Were online cleanup more effective, the salt would not be discarded and higher utilization } \\
\text { would be possible. In this case, Th utilization would be increased to a value limited by separations } \\
\text { losses similar to sustained recycle in other systems. }\end{array}$} \\
\hline
\end{tabular}




\subsection{Proliferation Resistance and Physical Protection}

Proliferation resistance and physical protection have been considered to varying degrees in early concept development and current assessments, see Table 4-3.

Table 4-3. Degree of Consideration of Proliferation Resistance and Physical Protection.

\begin{tabular}{|l|l|}
\hline \multicolumn{1}{|c|}{ Technology Family } & \multicolumn{1}{c|}{ Degree of Consideration } \\
\hline LWR with Th/U-233 fuel & $\begin{array}{l}\text { U-233 mass fraction per total heavy metal is less than 10\%. } \\
\text { Denatured option (U-233 mixed with U-238) has not been } \\
\text { considered. }\end{array}$ \\
\hline HTGR with U or U/Pu-239 fuel & Preliminary PR\&PP assessments have been performed. \\
\hline SFR breed and burn with U fuel & $\begin{array}{l}\text { U235 enrichment kept below 20\% for the initial core loading. } \\
\text { Several of these concepts deliberately have low refueling frequency, } \\
\text { as that is a desirable attribute in some PR\&PP evaluation } \\
\text { methodologies. }\end{array}$ \\
\hline MSR with Th/U-233 fuel & $\begin{array}{l}\text { Both denatured (U233 mixed with U238) and not denatured (highly } \\
\text { enriched U233) options have been considered. }\end{array}$ \\
\hline Fusion-fission hybrid & High-level assessments have been done. \\
\hline
\end{tabular}

\subsection{Safety}

Reactor physics safety considerations are accounted to different degrees in early concept development, see Table 4-4. It is therefore questionable to compare results for a case in which all the various reactor physics constraints such as negative power coefficients have been analyzed and met versus results for other cases in which one or more such constraints have not been studied.

Table 4-4. Degree of Consideration of Reactor Physics Safety.

\begin{tabular}{|l|l|}
\hline \multicolumn{1}{|c|}{ Technology Family } & \multicolumn{1}{c|}{ Degree of Consideration } \\
\hline LWR with Th/U-233 fuel & Feedback coefficients (power, temperature, etc.) need to be studied. \\
\hline HTGR with U or U/Pu-239 fuel & $\begin{array}{l}\text { Past work on reactor physics safety parameters was summarized. } \\
\text { Appears less of a constraint than for analogous LWR systems. }\end{array}$ \\
\hline SFR breed and burn with U fuel & $\begin{array}{l}\text { Feedback coefficients (power, temperature, etc.) and inherent safety } \\
\text { features in unprotected severe accidents need to be studied. }\end{array}$ \\
\hline MSR with Th/U-233 fuel & $\begin{array}{l}\text { Previous studies and experiments have shown acceptable feedback } \\
\text { coefficients, but an updated evaluation should be performed. }\end{array}$ \\
\hline Fusion-fission hybrid & $\begin{array}{l}\text { The fissile zone in each illustrative concept is intended to remain } \\
\text { subcritical. The degree of being subcritical is important to overall } \\
\text { neutron economy and fuel cycle performance. While super-criticality } \\
\text { can be avoided, new classes of accidents, such as source excursions } \\
\text { from plasma disruptions are possible. }\end{array}$ \\
\hline
\end{tabular}

Beyond reactor physics, the HTGR deep-burn report [Petti2009] and the HTGR fuel cycle study [Piet2010a] note an issue with decay heat following reactor accidents with high-burnup TRU-based fuels versus uranium-based fuels. This requires more analysis and could be an issue for a wider range of highburnup TRU-based fuel concepts. 


\subsection{Economics}

Based on the five studies, inadequate analyses have been done to provide much knowledge in this area. Necessary design-level information is not available at the current maturity of most of the subject technologies. 
This page intentionally left blank. 


\section{COMMON R\&D QUESTIONS}

As explained in chapter 1, the objectives of the five studies and this integrating report included identifying R\&D needs. In particular, in this chapter, we summarize six common R\&D questions.

Topic 1 - Parameters and metrics

The metrics and weighting values for metrics are uncertain. In the most holistic sense, what is more important uranium/thorium utilization or waste management? Is preparing to meet IAEA safeguards adequate in proliferation resistance, or are more technological limitations to be imposed? It must be remembered that each illustrative case in the five studies represents someone or some group's assessment (implicit or explicit) of what is most important. The illustrative cases would generally be altered to provide maximum performance, once maximum performance is defined. We also stress that each illustrative concept was shaped, in part, by considerations one does not find in existing lists of fuel cycle parameters or metrics. The nature of concepts often requires additional parameters or metrics to judge design possibilities within a technology family.

Topic 2 - Deployment

How soon could any new technology start deployment? How quickly could new technologies be deployed, in what sequence, to transition to a new technology or any fuel cycle other than the current once through? All commercial reactors in the US and 85\% of those in the world are LWRs. About $10 \%$ of the reactors around the world are heavy water, $4 \%$ are gas cooled, and $<0.5 \%$ are liquid metal cooled. Any non-LWR contribution to advanced fuel cycle strategies is constrained by new technology deployment.

\section{Topic 3 - Adaptability}

This report has just touched the surface of the adaptability issues that tend to arise in real systems adaptability of a technology family to a new fuel cycle mission and adaptability of a reactor (once built) to a new fuel cycle mission. This area deserves more study. For example, under what conditions could multiple fuels be used simultaneously in the same reactor? If adequate space (and neutrons) were available, it would seem possible for a given FFH to serve more than one fuel mission at a time. But, since HTGR pebbles with uranium versus TRU fuel have different masses (but same size), could one envision having a mix of uranium and TRU pebbles in the same reactor? Or, would one mix uranium and TRU fuel particles within a given pebble, so that each pebble was the same. Either is possible from a physics standpoint; the issue is fuel fabrication and performance.

Topic 4 - High fluence materials

Materials that can tolerate high fluence would benefit most of the concepts studied - especially advanced once through SFR, HTGR deep-burn, and several of the FFH options. On the other hand, physics limitations appear to constrain the burnup (hence fluence) of the LWR-Th/U-233 option so that development of high fluence capable materials would offer little value for that option.

Topic 5 - Disassembly of fuel meat from non-fuel structure

Even if the uranium and/or TRU fuel elements are not to be recycled, there can be a major reduction in mass disposed if methods are developed that separate fuel meat from non-fuel materials such as fuel assembly structure, solid moderators, cladding, and coating. 
Topic 6 - Quick study tools

There is always value in having new methods to approximate neutron economy in new concepts, to enable a quick assessment of what might be possible. Of course, quick assessments are sometimes wrong; so that if initial estimates are borderline, more detailed assessments are required. 


\section{CONCLUSIONS}

This chapter contains collective conclusions spanning the five studies and then a summary of the individual studies' conclusions.

\subsection{Collective Conclusions}

The studies provide a template for doing 1-year assessments of fuel cycle options, including a report template and examples of what can be accomplished with very modest-sized efforts.

- There is reasonable coverage of the performance areas of waste management and uranium utilization. The isotopic information will be collected and entered into the Transmutation Library.[Piet2010a]

- The coverage of economics, safety, and proliferation resistance and physical protection was spotty. Some studies had existing or past work to draw on in one or more of these areas.

- None of the illustrative cases in the five studies can be considered "reference" or "baseline" or "nominal" for their respective fuel cycle approaches. They were selected on the basis of available information and to explore the potential of each technology family to fulfill various types of fuel cycle missions. None are optimized.

- Little or no assessment was done of how soon any of the technologies could be deployed or at what R\&D cost, and therefore how quickly they could impact domestic or international fuel cycle performance.

Each of the study reports could be updated in the future as new information becomes available on the illustrative cases studied this year or as new illustrative cases are performed. In this sense, they can be considered living documents.

When a technology family is considered for use in a new fuel cycle mission, fuel cycle performance characteristics are dependent on both the design choices and the fuel cycle approach. For example, the use of the sodium-cooled fast reactor to provide recycle in either breeder or burner mode has been studied for decades, but the SFR could be considered for once-through fuel cycle with the physical reactor design and fuel management parameters changed. In addition, the sustained recycle with Th/U-233 in LWR could be achieved with a heterogeneous assembly and derated power density. Therefore, it may or may not be adjustable for other fuel cycle missions although a reactor intended for one fuel cycle mission is built. Simple parameter adjustment in applying a technology family to a new fuel cycle mission should be avoided and, if observed, the results viewed with caution.

If a reactor intended for one fuel cycle mission is built, it may or may not be adjustable for other fuel cycle missions if circumstances change.

- Examples where a change of fuel cycle mission is reasonable to contemplate include LWR or HTGR where (with some prior consideration in design) fuel can be shifted from uranium oxide (once through) to TRU-based IMF/deep-burn (single recycle) to UOX-TRU mixtures (sustained recycle).

- Examples where a change of fuel cycle mission is not reasonable to contemplate are LWR with uranium cannot be easily changed to sustained recycle with $\mathrm{Th} / \mathrm{U}-233$ while achieving desired performance and fusion-fission hybrids cannot be easily changed among waste burner, fuel factory, or once through deep-burn. (Such a change may be possible with reduction in system 
power level, assembly re-design, drop in burnup, and of course change in fuel type.) The inability of changing a facility once built in both these examples stems from physics. A harder neutron spectrum is required for Th/U-233 than $\mathrm{U} / \mathrm{Pu}$ fuel cycles. The three FFH illustrative cases each achieve desired performance with different neutron energies.

Table 6-1 summarizes the illustrative cases studied in the five studies of technology families, together with other parts of option space covered in previous studies and which parts may warrant future study.

Table 6-1. Option Space Summary

\begin{tabular}{|c|c|c|c|c|c|c|c|}
\hline $\begin{array}{l}\text { Recycle } \\
\text { or not? }\end{array}$ & \multicolumn{2}{|c|}{$\begin{array}{l}\text { What is } \\
\text { disposed? }\end{array}$} & $\begin{array}{l}\text { Light } \\
\text { Water } \\
\text { Reactor } \\
\text { (LWR) }\end{array}$ & $\begin{array}{c}\text { High } \\
\text { Temperature } \\
\text { Gas Reactor } \\
\text { (HTGR) }\end{array}$ & $\begin{array}{l}\text { Sodium Fast } \\
\text { Reactor } \\
\text { (SFR) }\end{array}$ & $\begin{array}{l}\text { Molten } \\
\text { Salt } \\
\text { Reactor } \\
\text { (MSR) }\end{array}$ & $\begin{array}{l}\text { Fusion- } \\
\text { Fission } \\
\text { Hybrid } \\
\text { (FFH) }\end{array}$ \\
\hline \multirow[b]{2}{*}{$\begin{array}{l}\text { Once } \\
\text { through }\end{array}$} & \multicolumn{2}{|c|}{$\begin{array}{l}\text { Unprocessed } \\
\text { used fuel }\end{array}$} & $\begin{array}{l}\text { Burnup } \\
\text { from } 33 \text { to } \\
100 \text { MWth- } \\
\text { day/kg }\end{array}$ & $\begin{array}{l}\text { Pebble bed, } \\
\text { Prismatic }\end{array}$ & Breed and burn & N/A & $\begin{array}{l}\text { Once through } \\
\text { deep-burn - } \\
\text { consume } \\
\text { fissionable } \\
\text { material }\end{array}$ \\
\hline & \multicolumn{2}{|c|}{$\begin{array}{l}\text { Process used } \\
\text { fuel only to } \\
\text { reduce } \\
\text { disposal } \\
\text { mass }\end{array}$} & $\begin{array}{l}\mathrm{N} / \mathrm{A}- \\
\text { relatively } \\
\text { little to be } \\
\text { gained }\end{array}$ & $\begin{array}{l}\text { Assembly/fuel } \\
\text { mass ratio is } \\
\text { high, reduce by } \\
\text { separating fuel } \\
\text { from bulk } \\
\text { graphite }\end{array}$ & $\begin{array}{l}\text { Assembly/fuel } \\
\text { mass ratio is } \\
\text { high, reduce by } \\
\text { separating fuel } \\
\text { from structure }\end{array}$ & N/A & N/A \\
\hline $\begin{array}{l}\text { Single } \\
\text { recycle }\end{array}$ & \multicolumn{2}{|c|}{$\begin{array}{l}\text { RU/DU, } \\
\text { fission } \\
\text { products, } \\
\text { used fuel }\end{array}$} & $\begin{array}{l}\text { IMF } \\
1 \text {-pass } \\
\text { MOX }\end{array}$ & $\begin{array}{l}\text { IMF (deep- } \\
\text { burn) in pebble } \\
\text { bed or } \\
\text { prismatic }\end{array}$ & $\begin{array}{l}1 \text { pass of } \\
\text { conventional } \\
\text { SFR }\end{array}$ & N/A & $\begin{array}{l}\text { Fissile fuel } \\
\text { factory - } \\
\text { make fuel for } \\
\text { use in other } \\
\text { reactors }\end{array}$ \\
\hline \multirow{4}{*}{$\begin{array}{l}\text { Sustained } \\
\text { recycle }\end{array}$} & \multirow{2}{*}{\multicolumn{2}{|c|}{$\begin{array}{l}\text { RU/DU, } \\
\text { fission } \\
\text { products, } \\
\text { and } \\
\text { processing } \\
\text { losses }\end{array}$}} & $\begin{array}{l}\text { U/Pu- } \\
\text { MOX, } \\
\text { Mix of } \\
\text { UOX \& } \\
\text { IMF }\end{array}$ & $\begin{array}{l}\text { MOX, } \\
\text { Mix of UOX \& } \\
\text { IMF (needs } \\
\text { more study) }\end{array}$ & $\begin{array}{l}\text { Conversion ratio } \\
\text { from } 0.0 \text { to } 1.0\end{array}$ & $\begin{array}{l}\mathrm{U} / \mathrm{Pu} \text { needs } \\
\text { study }\end{array}$ & $\begin{array}{l}\text { Dedicated } \\
\text { waste burner } \\
\text { - trans- } \\
\text { mutation of } \\
\text { fissionable } \\
\text { material that } \\
\text { was unused in } \\
\text { fission } \\
\text { reactors }\end{array}$ \\
\hline & & & Th/U-MOX & $\mathrm{Th} / \mathrm{U}$ & $\begin{array}{l}\text { Th/U needs } \\
\text { study }\end{array}$ & $\begin{array}{l}\text { Th/U } \\
\text { denatured, } \\
\text { Th/U with } \\
\text { periodic } \\
\text { salt } \\
\text { disposal }\end{array}$ & $\begin{array}{l}\mathrm{Th} / \mathrm{U} \text { a } \\
\text { logical } \\
\text { extension }\end{array}$ \\
\hline & \multirow{2}{*}{\multicolumn{2}{|c|}{$\begin{array}{l}\text { Fission } \\
\text { products and } \\
\text { processing } \\
\text { losses }\end{array}$}} & \multirow[t]{2}{*}{ N/A } & \multirow[t]{2}{*}{ N/A } & $\begin{array}{l}\mathrm{U} / \mathrm{Pu}- \\
\text { conversion ratio } \\
\text { from } 1.0 \text { to } 1.7\end{array}$ & $\begin{array}{l}\mathrm{U} / \mathrm{Pu} \text { needs } \\
\text { study }\end{array}$ & N/A \\
\hline & & & & & $\begin{array}{l}\text { Th/U needs } \\
\text { study }\end{array}$ & $\begin{array}{l}\mathrm{Th} / \mathrm{U} \\
\text { without } \\
\text { periodic } \\
\text { salt } \\
\text { disposal } \\
\end{array}$ & N/A \\
\hline \multicolumn{2}{|c|}{$\begin{array}{l}\text { Color legend in this } \\
\text { table }\end{array}$} & \multicolumn{2}{|c|}{$\begin{array}{l}\text { Previous program } \\
\text { studies }\end{array}$} & $\begin{array}{l}\text { Illustrative cases } \\
\text { these } 5 \text { studies }\end{array}$ & \multicolumn{2}{|c|}{$\begin{array}{l}\text { Limited information } \\
\text { in these } 5 \text { studies }\end{array}$} & $\begin{array}{l}\text { possibilities } \\
\text { nting study }\end{array}$ \\
\hline
\end{tabular}




\subsection{Individual Study Conclusions}

The final five subsections summarize the conclusions from the five individual studies.

\subsubsection{Multi-recycle LWR Th/U-233 [Yun2010]}

This report assessed the potential of LWRs to provide sustained recycle with Th/U-233 instead of U/Pu239. The initial intent was to determine if existing LWR designs could provide such sustained recycle, but this was broadened to consider the LWR technology family more generically.

\subsubsection{Feasibility}

A practical sustainable fuel cycle cannot be achieved with a typical homogeneous PWR assembly within the parameter space of initial U-233 content and reasonable moderator to fuel volume ratio (MR) obtained by varying the fuel pin size.

A 17-by-17 heterogeneous assembly design achieved the following attributes and partially met the requirements defined in this study for sustainable Th/U-233 multi-recycle:

- A derated core specific power density of $6.7 \mathrm{~W} / \mathrm{g}$, which is significantly lower than that of PWR of about $33 \mathrm{~W} / \mathrm{g}$.

- A 2.7-year cycle length with sustainable fissile inventory (assuming 3-batch fuel management), versus 1.5 -year cycle lengths.

- Discharge burnup of $18 \mathrm{GWth}-$ day/tonne, which is significantly lower than the burnup of current PWRs, which are approaching $50 \mathrm{GWth}$-day/tonne.

- The Th/U-233 system requires hard neutron spectra to support high conversion of Th-232. The neutron spectra of both the seed and the blanket region are harder compared to the standard thermal systems.

\subsubsection{Performance}

Compared to the used nuclear fuel of the standard PWR uranium-dioxide (UOX) fuel system, the high level waste (HLW) of the Th/U-233 multi-recycle system has lower normalized radiotoxicity and decay heat at discharge (due to lower burnup), but those become significantly lower after post-separation due to the recycle of $99.9 \%$ of $\mathrm{Th}$ and $\mathrm{U}$ isotopes in the nuclear system and the low production of transuranic elements.

Handling of the used fuel from the Th/U-233 system should generate less operational concern than for the UOX system because of the lower neutron source and photon source levels. The lower neutron source is due to the low production of TRU isotopes.

\subsubsection{Future work}

Cycle by cycle assembly physics models must be analyzed to ascertain if the same cycle length can be maintained in the succeeding recycles with the discharge fissile inventory derived from previous cycles.

A full-core model is necessary to estimate the neutron leakage and evaluate the performance of core level heterogeneity. 
A detailed thermal-hydraulics study should be carried out in future studies on the 17-by-17 heterogeneous assembly design for Th/U-233 multirecycle.

Considerations should be given to adopting hydride blanket fuel forms in future studies.

\subsubsection{High Temperature Gas Reactor [Piet2010b]}

The initial intent of this study was to assess the single recycle (deep burn) potential of HTGRs. This was broadened to also consider once through (primarily for comparison) and sustained recycle.

Several issues are outside the scope of this report, including the following: thorium fuel cycles, gascooled fast reactors, the reliability of TRISO-coated particles (billions in a reactor), and how soon any new reactor or fuel type could be licensed and then deployed and therefore impact fuel cycle performance measures. Although HTGR performance for some non-electrical missions requires advanced high temperature materials; these are not critical to fuel cycle missions and were not assessed.

\subsubsection{Feasibility}

The HTGR can serve all the fuel cycle missions that an LWR can; both are thermal reactors.

\subsubsection{Performance}

As the HTGR and LWR are both thermal neutron spectrum reactors, the report frequently compares the two as suggested by authors of the Option Study.[Wigeland2009] There are four major LWR-HTGR differences with fuel cycle implications - solid moderator, higher operating temperatures, higher fuel burnup associated with the TRISO fuel coating, and the "pebble bed" design approach (as opposed to the "prismatic" design approach, which is more directly comparable to LWRs).

The solid moderator has several effects. First, it means that there is no accident sequence involving voiding of the core's moderator. Thus, there is no void coefficient problem in HTGRs. The void coefficient issue in LWRs constrains TRU loading in recycled fuel (modified open cycle, full recycle).[Youinou2009] The lack of the void coefficient problem in HTGRs suggests MOC or full recycle HTGR could consume transuranics faster than a LWR. Second, carbon is a less effective moderator than hydrogen (or deuterium), leading to neutron energy spectral changes that slightly decrease uranium utilization relative to an LWR. This reactor physics disadvantage is compensated by the higher operating temperatures hence higher thermal efficiency. Third, the solid moderator in an HTGR (graphite) represents more of a waste management issue than the liquid moderator in an LWR (water). Heavy metal is $57 \%$ (BWR) to $70 \%$ (PWR) of the mass of LWR UOX assemblies, i.e., the discharged mass to be managed from used fuel is $\sim 1.5$ times that of the heavy metal. But, in the illustrative HTGR designs considered here, which are not optimized, the discharged mass to be managed is $\sim 19$ times that of the heavy metal. (Fast reactor designs are intermediate between LWRs and HTGRs in this regard, with discharged fuel assemblies being 3 to 12 times that of heavy metal.)

The high fuel burnup decreases the mass of used fuel that must be disposed (as HLW) in either the once through or modified open cycle. Higher burnup slightly decreases radiotoxicity in the once through fuel cycle or modified open cycle. A single recycle in either LWR or HTGR reduces radiotoxicity very little in uranium-TRU fuels (MOX) and 2-4x in all-TRU fuels (inert matrix fuels, a.k.a. deep-burn). Full recycle of all transuranics in any reactor reduces long-term radiotoxicity by $\sim 2$ orders of magnitude, assuming process loss rates below 1\%; For full recycle, the reduction of radiotoxicity in waste depends not so much on the reactor, but the number of times material is recycled and what the processing loss rate would be. The speed (number of recycles) required to attain such order-of-magnitude reduction is improved as the TRU loading increases, which is constrained by void coefficient in LWRs but not in HTGRs. 
The pebble bed design approach is outside common safeguard experience. LWRs, fast reactors, and prismatic HTGRs have fuel assembly masses in the range of 120 to $800 \mathrm{~kg}$; HTGR pebble bed have fuel pebbles about $0.2 \mathrm{~kg}$. (Each pebble has $\sim 50,000$ TRISO-coated fuel particles.) Thus, LWRs, fast reactors, and prismatic HTGRs have hundreds of fuel assemblies, which are easily counted as individual items. Pebble bed HTGRs have hundreds of thousands of fuel pebbles, e.g., the PBMR-400 design had 450,000 pebbles. These are thought to be counted as bulk material, not individual items. Moreover, the packing density of pebbles varies, making exact balance of the number of pebbles difficult; fortunately, several thousand pebbles are required to make up one "significant quantity" (SQ) of weapon-usable material.

\subsubsection{Future work}

Additional analyses are warranted to determine if HTGR "sustained recycle" service could provide improved consumption of transuranic (TRU) material versus LWRs (as expected), to analyze the unique proliferation resistance issues associated with the "pebble bed" approach, and to further test and analyze methods to separate TRISO-coated fuel particles from graphite and/or to separate used HTGR fuel meat from its TRISO coating. The feasibility of these two separation issues is not in doubt, but further R\&D could clarify separation efficiency, reduce cost, and enable options not adequately explored at present. The analyses here and the now-demonstrated higher fuel burnup tests (after the illustrative designs studied here) should enable future MOC and full recycle HTGR concepts to more rapidly consume TRU, thereby offering waste management advantages. Interest in "limited separation" or "minimum fuel treatment" separation approaches motivates study of impurity-tolerant fuel fabrication.

\subsubsection{Advanced once through in fast reactors [Kim2010]}

This study evaluated the potential for sodium fast reactors to serve the once through fuel cycle strategy. The systems studied include the CANDLE reactor of the Tokyo Institute of Technology, the sustainable sodium-cooled fast reactor (SSFR) by ANL, the fast mixed spectrum reactor (FMSR) by BNL, the ultralong life fast reactor (ULFR) by ANL, the General Atomics Energy Multiplier Module (EM²), and the traveling wave reactor (TWR) of TerraPower. Besides the PWRs, the other once-through nuclear systems are fast spectrum systems that have been proposed for achieving extremely long fuel residence time and high uranium utilization.

\subsubsection{Feasibility}

To meet the intended goals, the fast spectrum systems have adopted a design concept that is quite different from that employed for LWR. A breed and burn concept with propagating burn zone has been utilized with low power density, multi-batch fuel management scheme (in some cases), etc.

From a reactor physics standpoint, this category of concepts appears feasible. The engineering feasibility depends on a host of details and most notably high fluence-capable materials in most instances.

\subsubsection{Performance}

The fuel cycle performance parameters of these systems have been compared to those of the medium burnup PWR that has been considered as the reference system in this study. Results indicate that the reference PWR system discharges a used nuclear fuel (UNF) quantity of $\sim 20$ metric ton per GWe-year. On the other hand, the fast spectrum systems discharge 3-9 ton of UNF per GWe-year depending on the design choices. However, because of the higher breeding ratios of the fast spectrum systems, their plutonium production rate per GWe-year is higher than that of the reference LWR system.

Compared to the reference LWR system, the decay heat levels of the UNFs of the once-through fast spectrum systems are lower. At discharge, the heating level of the fast spectrum systems is 1- 4 
MW/GWe-year, which is about a factor of $10-40$ times smaller than that of the reference PWR. The UNF radiotoxicity has been evaluated using the ingestion dose coefficient specified by ICRP 72 . At ten years after discharge, the radiotoxicity values of the once-through fast-spectrum-system UNFs are about a factor of $2-5$ lower than for the reference system, because of the lower power densities in the oncethrough fast spectrum systems. At this time point, the fission products dominate the hazard, but the hazard associated with the shorter-lived fission products decreases quickly. The contribution from the actinides becomes dominant after 100 years. Subsequently, after about 1,000-100,000 years, the UNF radiotoxicity values of the once-through fast-spectrum-system are higher because of the contribution of the plutonium isotopes. It takes $\sim 200,000$ years for the PWR UNF radiotoxicity to become lower than that of the natural uranium material used in making the enriched uranium fuel for the system. On the other hand, it takes less or comparable time before the radiotoxicity values of once-through fast-spectrum-system UNF fall below the level of natural uranium ore: $\sim 120,000$ years for CANDLE, SSFR, and FMSR, and $\sim 200,000$ years for ULFR, EM ${ }^{2}$, and TWR.

As a measure of the used fuel handling difficulty, the neutron and photon source levels per unit mass of the used fuel were also evaluated. The once-through fast spectrum systems have a lower minor actinide production rate compared to the LWR system. Consequently, the neutron sources of the fast spectrum system are about a factor of $2-8$ smaller at discharge. Similarly, the fast spectrum systems have a lower photon source rate by a factor of $3-9$ at the discharge state. However, the high Cs-137 production rate of the fast systems results in a higher photon source level after 10 years.

The uranium utilization values for the systems have also been compared in this study. For the PWR systems, the uranium utilization is less than $1 \%$ regardless of the burnup. For the once-through fast spectrum systems, the uranium utilization could be increased to $\sim 30 \%$, depending on the core design choices. However, some technical design issues would have to be resolved in order for these core concepts to be practical.

\subsubsection{Future work}

More work is required on the engineering of these concepts.

\subsubsection{Thorium-fueled Molten Salt Reactor [Gehin2010]}

This study assessed the potential of thorium-fueled MSRs to provide sustained recycle.

\subsubsection{Feasibility}

The thorium-fueled MSR information is based primarily on the MSBR conceptual designs developed at ORNL for which significant information is available from the early 1970s. The uranium-fueled information is based on a later ORNL design for a Denatured Molten Salt Reactor (DMSR) that utilized both thorium and uranium.

MSR concepts can be envisioned as once-through, modified open, and full recycle fuel cycle approaches and the concepts mentioned above can be categorized under these approaches. The MSBR provides an example of a full recycle system in which the nuclear fuel is fully recycled with only fission products and other processing wastes being disposed. The DMSR could be considered in the once-through or modified open cycles based on the level of fuel processing that is performed. At the time of development, ORNL considered the system a once-through system but based on current definitions of the fuel cycle concepts, the DMSR is an example of a modified open system that involves minimal processing of the fuel, improved resource utilization (in comparison to LWRs) and with disposal of fuel as well as fission products. 


\subsubsection{Performance}

An assessment of these concepts has been performed based on a review of available documents and additional fuel cycle analysis to evaluate parameters related to waste management, used fuel storage, resource sustainability, proliferation resistance and physical protection, and economics. A summary of the assessment of the two MSR concepts is as follows:

- As a result of the use of thorium, both the MSBR and the DMSR waste have a very low TRU content in comparison with LWRs. The MSBR has a total TRU waste of $1.7 \mathrm{~kg} / \mathrm{GWe}-\mathrm{yr}$ and the DMSR has a total TRU waste of about $39 \mathrm{~kg} / \mathrm{GWe}-\mathrm{yr}$ in comparison to the reference LWR value of $220 \mathrm{~kg} / \mathrm{GWe}-\mathrm{yr}$. The DMSR has essentially no discharge actinide waste over its lifetime.

- Both the MSBR and the DMSR have an increased utilization of resources relative to the current once-through LWRs in terms of a lower heavy metal use per unit energy generation. The MSBR is 8-18 times lower and the DMSR is about 3 times lower than the LWR reference system.

- The MSBR has uranium that contains a high fissile content (70\%) and the associated fuel processing system produces a relatively pure stream of separated uranium. All of the uranium is contained within the reactor cycle and would require remote operations to gain access. The DMSR is designed such that enriched uranium is added to ensure that the uranium is maintained with a denatured LEU composition and there is no fuel processing system involved.

- An update of economics evaluation performed for the MSBR indicates a levelized electricity cost that is approximately $10 \%$ higher than the LWR reference. With a comparable reactor lifetime, the MSBR would have a levelized electricity cost that is comparable to the LWR reference.

- The MSR has safety advantages and disadvantages in comparison with the LWR reference. The advantages include low excess reactivity, lower radionuclide inventory, low pressure system, passive decay heat removal, fuel is already molten - fuel meltdown accident is not possible. Disadvantages include contamination of primary system, the enhanced production of tritium, high temperature operation, and chemical hazards associated with fuel processing system.

- While two molten salt reactors have been built and operated, the average technology readiness level can be characterized as "proof of principle" (TRL 5-6) and considerable research and development as well as significant amount of technology development will be required to bring the system to the level of commercial operation.

\subsubsection{Future work}

The work performed here represents a high-level review and assessment of MSR technology. Proposed future work includes:

- Completion of the assessment of the waste and proliferation resistance metrics not fully evaluated in this report.

- Assessment of a minor actinide burning MSR, such has been proposed elsewhere, as an additional modified open cycle concept. With these systems, the reactor is fueled with used LWR fuel with the fuel circulated to achieve a high burnup of actinides. Both thermal spectrum and fast spectrum systems should be considered along with the used LWR fuel processing based on fluoride volatility.

- DMSR design alternatives that are discussed in [Engel1978] and [Engel1980] can result in an improved operation with increased resource utilization. Alternative concepts include a system 
with breakeven breeding, partial fission product removal, and salt replacement to reduce fission product concentrations. In addition, the DMSR design discards a relatively large amount of thorium. Designs with decreased discharge of thorium should be considered.

- Development of tools to support MSR analysis should be considered. Current neutronics tools have limited capabilities to model MSRs and require approximations that impact the fidelity of the results.

\subsubsection{Fusion-fission hybrid [Halsey2010]}

This study considered the potential of FFH to provide the full range of fuel cycle strategies.

\subsubsection{Feasibility}

FFH might have several beneficial missions within future nuclear energy systems that appear feasible, including several that have unique characteristics unavailable to fission systems alone, such as:

- Waste incineration targeting radionuclides that are problematic for fission reactors

- Creation of fissile fuel for reactors without enrichment

- Full utilization of fissionable fuel without enrichment or reprocessing

Of course, the fusion fuel tritium must be used and, in most concepts, lithium must be isotopically enriched.

\subsubsection{Performance}

For FFH systems that complement fission reactors (waste burning, fuel production, ...), large support ratios are proposed, and thus the characteristics of the energy production system are likely to be dominated by the characteristics of the fission energy production reactors and their fuel cycle.

\subsubsection{Future work}

Technical maturity of FFH is paced by the technical maturity of the fusion driver. No fusion systems yet exist.

Costs for FFH systems cannot be accurately known at this time.

It is timely to consider how FFH technology might fit into advanced fuel cycle scenarios.

Development of fuel cycle models to incorporate FFH systems would be a useful step toward understanding the promise and problems of this technology.

Once fusion is demonstrated, FFH practicality may be paced by the complexity of combining fusion and fission technologies. 


\section{REFERENCES}

Ackoff1989

Bellinger

Dixon2008

Dixon2009

Gehin2010

Halsey 2010

$\operatorname{Kim} 2010$

Petti2009

Piet2010a

Piet2010b

Rose1986

Soelberg2010

Wigeland2009

Wigeland 2010

Yun2010
R. L. Ackoff, "From Data to Wisdom", Journal of Applied Systems Analysis, Volume 16, 1989, pp. 3-9.

Gene Bellinger, Durval Castro, Anthony Mills, "Data, Information, Knowledge, and Wisdom," http://www.systems-thinking.org/dikw/dikw.htm, accessed September 19, 2010.

B. W. Dixon, William Halsey, Sonny Kim, Gretchen Matthern, Steven Piet, David Shropshire, "Dynamic Systems Analysis Report for Nuclear Fuel Recycle," Revision 1, AFCI-SYSA-AI-SS-RT-2009-000053, Advanced Fuel Cycle Initiative, December 2008.

B. W. Dixon, Fuel Cycle Metrics Review, FCR\&D-SYSA-2010-000025, December 24, 2009.

Jess Gehin, Lou Qualls, Harold Smith, Kent Williams, "MSR Molten Salt Reactor Fuel Cycle Technology Assessment," August 23, 2010.

W. Halsey, Fusion-Fission Hybrid Fuel Cycle Technology Assessment, FCR\&DSYSA-2010-000139, LLNL-TR-451392, August 23, 2010.

T. K. Kim and T. A. Taiwo, "Fuel Cycle Analysis of Once-Through Nuclear Systems," ANL-FCRD-308, August 10, 2010.

D. A. Petti, et al, "Deep-burn: Development of Transuranic Fuel and Fuel Cycles for High Temperature Gas-Cooled Reactors," September 2009.

Steven J. Piet, Samuel E. Bays, Edward A. Hoffman, "Description of Transmutation Library for Fuel Cycle System Analyses," FCRD-SYSA-2010-000116, INL/EXT-1019545, August 4, 2010.

Steven J. Piet, Samuel E. Bays, Nick R. Soelberg, "HTGR Technology Family Assessment for a Range of Fuel Cycle Missions," FCRD-SYSA-2010-000130, August 23, 2010.

David J. Rose, Learning About Energy, Plenum Press, 1986.

N. R. Soelberg, S. J. Piet, S. E. Bays, R. N. Henry, D. H. Meikrantz, T. A. Taiwo, T. K. Kim, D. Yun, J. Gehin, L. Qualls, K. Williams, W. Halsey, "Waste Stream Analyses for Nuclear Fuel Cycles", Idaho National Laboratory, FCRD-SYSA-2010000109, INL/EXT-10-19643, August, 2010.

R. Wigeland, T. Taiwo, M. Todosow, W. Halsey, J. Gehin, “AFCI Options Study," AFCI-TIO-PMO-MI-DV-2009-000086, Advanced Fuel Cycle Initiative, September 2009.

R. Wigeland, T. Taiwo, M. Todosow, W. Halsey, J. Gehin, "Options Study - Phase II," FCRD-TIO-2010-000167, Fuel Cycle Research and Development Program, September 2010.

D. Yun, T. K. Kim, T. A. Taiwo, “Th/U-233 Multi-recycle in PWRs," ANL-FCRD309, August 11, 2010. 